\title{
Tüketicilerin Otomobil Satın Alma Davranışlarına Etki Eden Faktörlerin Belirlenmesi: Akademisyenlere Yönelik Bir Uygulama
}

\author{
Determining Factors Affecting Consumers' Purchasing Behaviors: An Application \\ for Academicians \\ A.Selçuk KÖYLÜOĞLU* \\ Ö.Emrah ACAR \\ Ü.Saliha EKEN INAN"**
}

\begin{abstract}
ÖZ
İsletmelerin, hassasiyetle üzerinde durduğu konular arasında pazarlama ve pazarlamanın yakın ve uzak çevresindeki paydaşlarla senkronize uyumu yer almaktadır. İşletmenin varllğını devam ettirebilmesi için hayati önem teşkil eden müşteri, bu paydaşların başında gelmektedir. Bu anlayışla, tüketici davranışını etkileyen faktörlerin araş̧tııldı ̆̆ bu çalışmada amaç, akademisyenlerin araç satın alma davranışlarına etki eden faktörleri incelemektir. Otomobil, insanların ulaşım gibi temel ihtiyaçlarını karşılamanın yanı sıra sosyal ve psikolojik ihtiyaçlarına da cevap verebilmektedir. Akademisyenler ise toplumda önemli bir yere sahiptir. Bu doğrultuda, Selçuk Üniversitesi akademisyenlerinin araç satın alma davranışları anket yöntemiyle araştırılmıştır. Anket soruları demografik özelliklere ve psikolojik faktörlere göre hazırlanmıştır. Bu çalışma için Dongyan ve Xuan tarafindan 2008 yllında yapılan "Pekin'de Otomobil Satın Alma Davranışları: Ampirik Bir Araştırma" isimli yüksek lisans tezinden faydalanılmıştır. Akademisyenler rastgele örneklem seçimi ile belirlenmiş ve anket formlart yüz yüze görü̈sülerek doldurulmuştur. Toplamda 135 anket cevaplanmıştır. Elde edilen veriler SPSS/Windows 2.0 sürümü istatistik analiz programına uygun olarak kodlanmiştır. Fark testleri, regresyon analizi ve anova testi gibi çalıșmanın amacına uygun testler analiz edilmişstir. Sonuç olarak \%5 anlamlllık düzeyinde genel memnuniyet düzeyi değişkenini açıklamada marka, parasal değer ve sürüss konforu istatistiksel olarak anlamlı bulunmuştur. Bu açıklayıcılığa en büyük katkıyı marka değişkeninin sağladı̆̆ı görülmüştür.
\end{abstract}

ANAHTAR KELIMELER

Otomobil, Satın Alma Davranışı, Tüketici

\begin{abstract}
Among the issues that businesses emphasized with precisely are synchronized harmony between the marketing with close and distant stakeholders of marketing. The customer, who is crucial to the survival of the enterprise, is at the forefront of these stakeholders. In this respect, the purpose of this study, which is investigate the factors affecting consumer behavior, to examine the factors affecting the buying behavior of academicians. In addition to meeting the basic needs of people such as transportation, the car can also respond to social and psychological needs. Academicians have an important position in society. In this regard, Selcuk University academicians car buying behaviors were investigated by questionnaire method. Survey questions were prepared according to demographic characteristics and psychological factors. For this study, benefited from a master thesis that is titled: "Car Buying Behavior in Beijing: An Empirical Research" by Dongyan and Xuan in 2008 was used. The academicians were selected by random sample selection and the questionnaires were filled in face to face. In total 135 questionnaires were answered. The obtained data recorded according to the statistical analysis program of SPSS / Windows 2.0 version. Difference tests, regression analysis and anova test which are suitable for the purpose of the study have been analyzed. As a result, brand, monetary value and driving comfort were statistically significant in explaining the general satisfaction level variable at the level of 5\% significance. It is seen that this explanatory variable is provided by the largest contribution brand variable.
\end{abstract}

\section{KEYWORDS}

Automobile, Buying Behaviour, Consumer

* Öğr.Gör.Dr., Selçuk Üniversitesi, Sosyal Bilimler Meslek Yüksekokulu, selcuk641@gmail.com

** Dr., Selçuk Üniversitesi, Sosyal Bilimler Enstitüsü, omeremrahacar@hotmail.com

**** Öğr.Gör., Selçuk Üniversitesi, Sosyal Bilimler Meslek Yüksekokulu, saliha_eken@hotmail.com 


\section{GİRIŞ}

Yeni küresel ekonomi sistemi, işletmeleri sürekli değişen çevre şartlarının söz konusu olduğu dalgalı ve belirsiz ortamlarda faaliyette bulunmaya zorlamaktadır. Ve pek tabii bahsedilen olgu sadece çağdaş yapıya sahip organizasyonlara has olmayıp, her organizasyon açısından yaşam biçimi ve felsefe haline gelerek, şirketlerin başarısında önemli bir unsur kabul edilmektedir. Böylesi yıkıcı bir rekabet ortamının hüküm sürdügü yeni ekonomi modelinde üstün olmak isteyen işletmeler için çevreyle sürekli uyum içinde olmak ve değişimleri anbean takip ederek gerekli bilgiyi elde etmek önem arz etmektedir. Bu tür güncel ve rekabetçi bilgi içerisinde insanların niçin, nasıl ve ne zaman satın aldıklarını bilmek ve bunların davranış dinamiklerini göz önünde bulundurmak hiç şüphesiz organizasyonların yaşam süresini pozitif yönde etkileyecektir (Mukherji vd., 1998: 265-273; Tekin vd., 2010: 2; Oluç, 2006: 737).

Birçok kesişimi içinde barındıran bu yeni oluşumda tüketicinin üstlendiği rol, varlığını bariz bir şekilde hissettirmektedir. Zira bahsi geçen dönemde var olanla yetinen ve çabuk kabullenen pasif tüketici, yerini, pazarı hâkim kılma yetkinliğine sahip, donanımlı, aktif bir tüketici profiline bırakmıştır. Bu tespit için postmodern tüketici tabirinin yerinde bir söylem olacağı yeni tüketici profilinin, gelenekselin çok ötesinde, modern tüketici karakteristiğinden uzak, sosyal tabaka, davranış ve demografik özellikleri gibi tahmin edilebilecek birden fazla değişkeni farklılık göstermektedir. Bu farklılığın özünde yatan temel neden, kuşkusuz tüketimin üstlendiği roldür. Çünkü modern ekonomi anlayışına kadar hatta kısmen de olsa modern ekonomi anlayışında üretim ön planda iken, postmodern günümüz ekonomi anlayışında tüketim olgusu dominanttır. Tartışmasız bu değişimler beraberinde üretim ve tüketimin esnekleşmesi ile tüketicinin beklenti ve gereksinimlerine uygun üretimin icra edilmesinin yanı sıra bilginin meta haline gelerek bilgi ekonomilerinin oluşmasının da bu yeni akıma adapte olduğu görülmektedir. Ürünün fiziksel ve fonksiyonel özelliklerinden ziyade, onun imajını daha çok önemseyen yeni tüketici eğilimi, elbette bu yeni ekonomi ve sosyo-kültürün önemli bir elemanıdır. Bu kültürde önemli olan husus firsat maliyetlerini ortadan kaldırırcasına minimize ederek ürün ya da hizmetlerden birini tercih etmek değil, ikisini bir araya getirerek daha fazla değer yüklemek olacaktır (Burton, 2002: 792-810; Doğan, 2002: 21-39).

$\mathrm{Bu}$ anlayışla son dönemde Türkiye' de otomobil sektöründe yaşanan gelişmeler dikkat çekmektedir. Türkiye' de 2015 yılında 1.000 kişiye düşen otomobil sahipliği 183 adede ulaşmıştır. Ancak dünyaya bakıldığında Batı Avrupa' da bu oran her bin kişide 612, Doğu Avrupa' da ise 306 düzeylerinde gerçekleşmiştir. Türkiye otomotiv sektörü 2016 yılı toplam pazarı bir önceki döneme kıyasla \%2,8 azalarak 738 bin 93 adet, üretim ise \% 6,5 artarak 1 milyon 179 bin adet olarak gerçekleşmiştir. Otomobil satışları 2016 yılında bir önceki y1la göre 0,77 artarak 553 bin 111 adede ulaşmıştır. Görüldüğü üzere Türkiye otomotiv sektörü, küresel otomotiv sektörünün vazgeçilmez bir paydaşı konumundadır. Bu sektör, iç pazar satışlarıyla dünya ülkeleri sıralamasında17., Avrupa otomotiv satışlarına göre de 6. sırada yer almaktadır. Bunun yanı sıra Avrupa' ya en fazla ihracat yapan ülke konumundadır. Şüphesiz otomotiv üretiminde de Türkiye kendini göstermektedir. Dünyada 15., Avrupa otomotiv üretiminde de 5. sırada bulunmaktadır. Sektörün 2017 y1lı iç Pazar tahmini ise, 950 bin-1 milyon bandındadır. Ancak adı geçen tahminler yapılırken küresel arenada meydana gelen; FED para politikasındaki normalleşme süreci ve faiz artırma beklentisi, Brexit kararının yansımaları, AB' deki dalgalanmalar doğrultusunda Avrupa Merkez Bankası' nın uygulayacağı politikalar, Çin' in özellikle gelişmekte olan ülkelere etkisi ve jeopolitik ve jeostratejik gelişmeler gibi pek çok parametreyi dikkate almak sektör açısından hayati önem taşımaktadır (Erce, 2016: 3). Otomobilden çeşitli amaçlarla yararlanmak ve onu kullanmak tüketicilerin otomobil satın almasının esasını teşkil etmektedir. Güç gösterimi, saygınlık, prestij elde etme gibi kaygılar da göz ardı edilmemelidir. Kolaylık sağlaması, özgür bir yaşam şeklindeki otomobil algısı da bir gerçektir. Ne var ki, asıl üzerinde durulması gereken, tüketicilerin neden satın aldığı veya almadığı ile hangi faktörlerin satın alma davranışı üzerinde baskın olduğudur (Arslan, 2003: 83). 
Otomobil alımında tüketici davranışlarının incelendiği bu çalışmada, tüketicilerin otomobilleri hangi gereksinime dayanarak satın aldığı, hangi marka ve modellerin tatmin ettiği ve buna nasıl karar verildiği, pazarlama bileşenlerini etkileyen etmenlerin neler olduğu, neye göre seçim yapıldığı ve bu süreçte hangi faktörlerin ön plana çıktığı türünden sorulara cevap aranmıştır. Buradan hareketle öncelikle tüketici, tüketim, satın alma davranışı gibi temel kavramlar açıklanacaktır. Ardından konuyla ilgili literatürde yapılan çalışmalar hakkında bilgi verilecektir. Akabinde çalışma yöntemi açıklanarak, araştırma bulgularının ortaya konulmasıyla ilişkiler değerlendirilip analiz edilerek sonuçlandırılacaktır.

\section{KAVRAMSAL ÇERÇEVE}

\section{Tüketim, Tüketici, Tüketici Davranışı ve Özellikleri}

Tüketimin insan istek ve ihtiyaçlarının karşılanması gayesiyle mal ve hizmetlerin kullanılması olduğu bilinmektedir. Bu anlayışla, tüketim işlemini gerçekleştiren kişi veya kurumlara tüketici denir iken, tüketiciler şahıslar olabileceği gibi kurumlar olabileceği de unutulmamalıdır. Odabaşı ve Barış (2014)' e göre tüketici; son kullanım amacı ile ürün ve hizmetleri satın alan ve kullanan kişidir. Karabulut (1989) tüketiciyi, arzu ve gereksinimlerini karşıllamak maksadıyla pazarlama bileşenlerini satın alan ya da bu potansiyele sahip olan gerçek kişi olarak tarif etmektedir. Kotler (2000a), başka bir ürün ile entegre etmek veya kullanmak üzere satın alma eyleminde bulunan kişi veya kuruluş olarak tanımlamaktadır. 4077 ve 6502 Sayılı Tüketicinin Korunması Hakkındaki Kanun (2014)' e göre, tüketici tanımları karşılaştırıldığında; 4077 sayılı kanunda tüketici, bir mal veya hizmeti ticari veya mesleki olmayan amaçlarla edinen, kullanan veya yararlanan gerçek ya da tüzel kişi olarak açılanmaktayken, 6502 sayılı kanun, ticari veya mesleki olmayan amaçlarla hareket eden gerçek veya tüzel kişi olarak açıklamaktadır. TSE ise, varlığını sürdürülebilir kılmak maksadıyla ürün ve hizmet edinip kullanan ve bunları satın alan her kişiyi tüketici olarak kabul etmektedir (Odabaşı ve Barış, 2014:20; Karabulut, 1989; Kotler, 2000a:116; Ankara Barosu Tüketici Hakları Kurulu, 2014:12-15; TSE Standart ve Teknik Dergisi, E.T. 2015).

Tek (1990), tüketiciyi, mal ve hizmetleri başka mal ve hizmetlerin üretimi için olmayıp, büsbütün menfi ve hane halkı gereksinimleri karşılamak için kullanan kişi olarak tanımlamaktadır. Amerikan Pazarlama Derneği (2015) tüketiciyi, ürün ya da hizmetlerin gerçek veya muhtemel alıcısı olarak tarif etmektedir. Son olarak bir başka tanımda da tüketici, tüketim amacıyla mal ve hizmet kullanan insanlar olarak açıklanmaktadır (Tek, 1990:124-125; Amerikan Pazarlama Derneği, E.T. 2015).

$\mathrm{Bu}$ tanımlamalar öncülüğünde ifade edilmeye çalışıldığg gibi, hayatın büyük bir bölümünün tüketimle geçtiği düşünülürse, tüketim eylemlerinin bir amacı da tüketicinin bilinçlendirilmesi olmaktadır. Aslında tüketicilik bilinci, iyi bir tüketicinin bilmesi gereken ve adapte edilebilen davranış kurallarını icra etme ve bu ortamı oluşturma olgusudur. Bu sebeple iyi bir tüketici sahip olduğu hakların farkında olmalı ve bu hakları kullanmayı bilmelidir. Bu açıdan iyi bir tüketicide bulunması gereken özellikler şu şekilde sıralanabilir (Durmaz, 1999:1-3): İyi bir tüketici dikkatli ve araștırmacı olmalı, kaliteli malı ucuza alabilmeli, fiyatı karşılaştırmalı olarak birçok yönden incelemeli, tanınmış markaları tercih sebebi kılmalı ve son olarak satın alma anı itibariyle risk azaltıcı karar verme eğiliminde olmalıdır.

Tüketici ile ilgili yapılan tanım ve açıklamalar, tüketici davranışı kavramına da zemin hazırlamıştır. Zira modern pazarlama anlayışı tüketici davranışının aynı istek ve ihtiyaçlara sahip geniş kitleler olarak algılanamayacağına dikkat çekmektedir. Tüketicilerin beklentileri zaman içinde değişmekle birlikte, alıcıların ihtiyaçları noktasındaki benzerlikler ve farklılıklar da temel tüketici istekleri alt gruplarına ayrılmaktadır. Sonuçta homojen hale getirilebilmiş tüketici grupları, işletmelerin pazardaki istek ve ihtiyaçları idrak etmelerini kolaylaştıracak ve müşteri merkezli olmaları hususunda önemli bir adım olacaktır (Boyraz, 2012: 45-49; Uzunoğlu, 2005: 73). 
Tüketici davranışıyla ilgili yapılan tanımlardan birinde; bireylerin mal ve hizmetleri elde etmeleri ve kullanmalarıyla ilgili eylemlerin ve bu eylemler öncesinde gelen ve onları belirleyen süreçleri içerdiği belirtilmektedir. Altunışık vd. (2001)' e göre, tüketici davranışı ihtiyacın hissedilmesi anında başlayan, söz konusu ihtiyacın giderilmesi noktasında satın alınan mal ya da hizmetin kullanılması ve sonrasında sağlanan faydanın değerlendirilmesini de kapsayan bir süreçtir. Tenekecioğlu (2009), ürün ve hizmetlerin seçilmesi, satın alınması ve kullanılmasını da kapsayan faaliyetler olarak tarif etmektedir. Odabaşı ve Barış (2014)' e göre, kişinin öncelikle ekonomik ürünleri ve hizmetleri satın alma ve kullanmadaki kararları ve bunlarla ilgili faaliyetleridir. Son olarak Tek (1990), ekonomik mal ve hizmetleri elde etme ve kullanmalariyla direkt olarak alacaklı aktiviteler ve bahsi geçen aktiviteleri belirleyen karar süreçleri olarak tanımlamaktadır (Altıntaş, 2001; Oluç, 2006: 738; Altunışık vd., 2001: 53-56; Tenekecioğlu, 2009: 68).

Satın alma davranışında tüketici davranışı özelliklerinin bilinmesi, işletmelerin varlığının uzun soluklu olması açısından hayatidir. Wilkie, işletmeler açısından elzem olan bu özellikleri şu şekilde sıralamaktadır: (Wilkie 1986' dan aktaran Odabaşı ve Barış, 2014: 30): Tüketici davranışı güdülenmiş bir davranıştır, kimi ani kimi de tedrici olarak gelişir ve satın alma deneyimlerini kapsayan çeşitli faaliyetlerden oluşur, tüketici davranışındaki değişimler fiziksel, sosyal, ekonomik, sosyo-kültürel ve demografik çevre faktörlerinden etkilendiği için tüketici davranışı çevre faktörlerinden etkilenir özelliğini teyit eder niteliktedir, tüketici davranışının tahlili farklı davranışların nedenlerini ortaya koymakla mümkün olmaktadır, zamanlama ve karmaşıklık açısından ayrımlılık gösteren davranışlardır ve tüketici davranışı başlatıcı, etkileyici, karar verici, satın alıcı ve kullanıcı gibi farklı rollere bürünebilmektedir.

\section{Tüketici Davranışı Modelleri}

Özünde tüketicinin satın alma davranışının kastedildiği tüketici davranışını açıklamak için sistematik modeller geliştirilmiştir. Bu modeller kendi bilim dallarında ve sosyal bilimlerde geliştirilen modeller olup, tüketici tercihi konusuna hatırı sayılır katkılar yapmıştır. Sözü edilen modeller, tüketici davranışlarının çözümlenmesini ve gerçeğin basite indirgenerek anlaşılmasını kolaylaştırmaktadır. Böylelikle tüketici davranışlarının idrak edilmesinin zor ve karmaşık olduğu bu süreçte, ilgili bölümler incelenerek konunun özü yakalanmaya çalışılmaktadır. Modeller üç grup halinde sıralanabilir. Birinci grup modeller, sadece tüketicinin ortaya davranışı değil, aynı zamanda onunla ilgili olarak bazı etmenleri de incelemeyle ilintilidir. İkinci sırada yer alan modeller, tek başına tüketici davranış sürecini ele alan yaklaşımı açıklamaktadır. Bu modelin iki önemli dayanak noktası vardır: İlk aşamayı modeli açıklayan genel kuramın belirlenmesi oluştururken, ikinci aşama tüketici davranışlarının özgül izahatlarından oluşmaktadır. Son grup olan üçüncü model tipi ise, tüketicinin sadece ortaya çıkan davranışlarını incelemektedir (Papatya, 2005: 223; Karabulut, 1989: 18-25).

Tüketici karar modelleri; Maslow’ un İhtiyaçlar Hiyerarşisi Modeli, Marshall Ekonomik Modeli, Freud Psiko-Analitik Modeli, Pavlov Öğrenme Modeli, Veblen Sosyo-Psikolojik Modeli, Nicosia Modeli, Howard Sheth Modeli, Engel-Kollat ve Blackwell Modeli, Andreasan Modeli, Katona Modeli, Lazersfeld Modeli, Hawkins-Best ve Coney Modeli, Howard Ostland Modeli, March ve Simon Modeli, Gestalt Kuramı şeklinde suralanabilir.

Endüstriyel alıcılar için geliştirilen modeller ise, Webster ve Wind' in Genel Modeli, Henry Assael Modeli, Robinson-Faris ve Wind Modeli, Sheth İnteraktif Modeli, Nelson Kutu Modeli, Hobbesian Kurumsal Alıc1 Modeli, Reward Ölçüm Teorisi, Rol Teorisi, Satın Alma Belirleyici Teorisi şeklindedir (Essien ve Udo-Imeh, 2013: 55-56).

\section{Tüketici Satın Alma Kararını Etkileyen Faktörler}

İnsanın sosyal bir varlık olması, ona çevresi ile sürekli etkileşim halinde olmayı dayatmaktadır. Her toplum, hayat görüşleri ve sosyal nedenleri ile fert ve ailelerden meydana gelen sosyal gruplara ayrılmakta ve her sosyal grup sosyal itibarına göre toplum içinde bir derecelendirmeye tabi tutulmaktadır. Bu ve benzeri nedenlerden 
dolayı tüketici davranışları ve satın alma kararları kültürel, sosyal, kişisel ve psikolojik olmak üzere pek çok faktörden etkilenmektedir. (Oluç, 2006: 738; Çağlar ve K1lıç, 2005: 75).

\section{Kültürel Faktörler}

Biyolojik olarak bir genelleme yapılacak olursa, diğer canlıların içgüdüleriyle hareket etmelerinin aksine, bilinçli ve bilinçsiz insan davranışları ancak öğrenilerek bir forma kavuşmaktadır. Bu bakımdan homojen bir grup insana ait etmenden oluşan ve tüketici davranışını etkileyen kültürel faktörleri kültür, alt kültür ve sosyal sınıf olarak alt unsurlar şeklinde ele almak gerekmektedir. (Karabacak, 1993: 85).

Kotler (2000a) için kültür, bir kimsenin istek ve gereksinimlerinin en önemli belirleyicisidir. Bir başka tanımda, başkalarının yetenekleri, gelenekleri ve görenekleri ile bilgi, din, sanat, inanç ve konuların bileşimi olarak nitelendirilmektedir. Bu açıklamalar doğrultusunda pazarlamacılar, tüketicilerin kültürel değerleri ve yaşanan kültürel değişmeleri dikkate almak ve bu perspektifle hareket etmek durumundadır (Luna ve Gupta, 2001: 45-69; Oluç, 2006: 740; Durmaz, 1999: 65).

\section{Sosyal Faktörler}

Tüketici karar sürecinde bireylerarası determinantların en önemlilerinden bir tanesi de kişinin aile çevresidir. Hanehalkı üyeleri satın alma kararında önemli rollere sahiptir. Çünkü bireyler aile üyeleriyle sürekli etkileşim halindedir. Dolayısıyla aile, birey üzerindeki grup etkisinin en güçlü kaynağıdır. Aile üye sayısına, evlenme biçimlerine, oturma yerine ve otoritenin dağılımına göre sınıflandırılabilir (Oluç, 2006: 744; Odabaşı ve Barış, 2014: 245).

Ailenin gereksinim ve harcamaları çocuk sayısı ve dişarıdan bütçeye yapılan katkılara göre değişiklik göstermektedir. Bu açıdan ürün tercihleri ve ihtiyaçlar da farklılık arz etmektedir. Özellikle günümüz aile yapısının yaşlı bir niteliğe sahip olması daha nitelikli ve özellikli ürün trendine olan talebin arttığını da göstermektedir (Cömert ve Durmaz, 2006: 356). Tüketici davranışı penceresinden, ailenin ataerkil ya da anaerkil bir yapıya sahip olması karar verme açısından otoritenin dağılımına göre toplumlar nezdinde farklılık göstermektedir. Ataerkil aile yapısında babanın kararı mutlak ve sonsuz iken, anaerkil aile yapısında annenin egemenliği kesin ve mutlaktır. (Odabaşı ve Barış, 2014: 246-248). Ailede yer alan fertler kendi ihtiyaçları için tüketimde bulunabilecekleri gibi, bir tüketim biriminin nam ve hesabına da hareket eden tüketici durumunda da olabilirler. Bu vesileyle aile, bir malın piyasasını meydana getiren en küçük tüketim ünitesidir. Bu söylemle bir arada yaşayan, müşterek bir tüketim modeline sahip olan fertlerin meydana getirdiği insan grubu kastedilmektedir. Bahsedilen tüketim ünitesinde satın alma kararları incelendiğinde pek çok araştırmaya rastlanmaktadır. Ailede ürünün satın alınmasına karar veren, ürünü kullanan ve satın alanlar farklı olabilmektedir. Dolayısıyla pazarlamacılar hata payını minimize ederek, hedefi doğru aile ferdine yönlendirmeye çalışmalıdırlar (Martin ve Bush, 2000: 441-443; Durmaz, 1999: 69; Odabaşı ve Barış, 2014: 248).

Bir diğer önemli etmense referans gruplarıdır. Bir kimsenin referans grubu, tutum ve davranışların şekillenmesinde direkt ya da endirekt etkiye sahiptir. Söz konusu gruplar, bu yüzyılda modern toplum üyelerinin kimi zaman üyesi dahi bulunmadığı sosyal grupların tesiri altında kalmasına neden olmakta ve tüketici davranışının tespitini zorlaştırmaktadır. Bir kişi satın alma kararını verirken, bahsedilen referans grubunu göz önüne alarak onların satın aldığı malları almak isteyebilir. Bu gruplar, birincil/ikincil, formal/informal ve sembolik gruplar başlığı altında toplanmaktadır (Hatiboğlu, 1993: 43-44; Durmaz, 1999: 67; Karafakıoğlu, 2006: 104). Bu gruplara ilave olarak tüketicilerin davranışları üzerinde etkisi olan diğer gruplar bağlantılı, özenilen, reddedilen ve kaçınılan gruplar olmak üzere dört başlık altında toplanabilir (Deniz, 2011: 250-251; Tenekecioğlu, 2009: 71-72). Sosyal faktörlerin son alt unsuru, sosyal rol ve statülerdir. Bir 
kimsenin her gruptaki mevkisi, onun rolü ve statüsü ile ifade edilebilir. (Mathur, vd., 2003: 129-132; Tenekecioğlu, 2009: 74; Deniz, 2011: 252).

\section{Kişisel Faktörler}

Kültürel ve sosyal faktörlerin ardından tüketicilerin satın alma kararlarını etkileyen kişisel faktörler demografik ve durumsal faktörler olmak üzere iki gruba ayrılmakla beraber, yaş ve yaşam dönemi aşamaları, meslek, ekonomik şartlar ve yaşam tarzı gibi alt başlıklardan oluşmaktadır. Demografik faktörler yaş, cinsiyet, medeni hal, gelir, eğitim ve meslek gibi bireysel özelliklerden oluşmaktadır. İlk etapta kişinin yaş ve hangi yaş döneminde bulunduğu, onun hangi mallara yöneleceği konusunda etkilidir. Benzer şekilde evli veya bekâr olması, çocuk sahibi olup olmadığı, cinsiyeti, gelir durumu, mesleği ve eğitim düzeyi, hayat tarzı gibi etmenler de söz konusu faktörler arasında yer almaktadır (Deniz, 2011: 253). Bireyin mesleği ve paralelinde öğrenim düzeyi, belirli mallara olan istek ve ihtiyacı ortaya koymakta ve bu açıdan etkili olmaktadır. (Milli Eğitim Bakanlığı, 2012: 25; Cemalcılar, 1999: 55).

Bir kimsenin satın alma gücü varsa, o mal veya hizmetin potansiyel alıcısı olabileceğinden, demografik özelliklerin yanında ekonomik etkilerin de rolü yadsınamaz. Zira genel bir ekonomi içinde varlığını devam ettirmek zorunda olan tüketici enflasyon, faiz, GSMH, GSYH, MG...vb. ekonomik parametrelerle yüz yüzedir. Bu ekonomik sistem içerisinde ise gelir, temel etkendir. Kişisel gelirden vergiler ve vasıtasız gelir farkı alındıktan sonra harcanabilir gelire ulaşı1ır. Diğer önemli bir gelir kalemi de aile geliridir. Aile geliri, tüm kişilerin gelirlerinin toplamıdır. Buna ek olarak tüketici kredileri, taksitli satışlar, vade erteleme gibi opsiyonel satışların da talep üzerindeki etkisi büyüktür. Bu nedenle tüketicilerin harcama modellerinin incelenmesi ve geleceğe yönelik tahminler yürütülmesi, pazarlama açısından önem arz etmektedir (Durmaz, vd., 2011: 119: Durmaz, 1999: 44-45).

Kişisel faktörlerin ikinci önemli sac ayağı ise durumsal faktörlerdir. Durumsal faktörler, zaman ve fiziksel çevre gibi iki önemli unsurdan oluşmaktadır. Fiziksel çevre, insanların ruhsal durum ve davranışlarını etkilemektedir. Dolayısıyla ekolojik, sosyal, ekonomik ve politik çevrelerin satın alma kararı üzerindeki etkisi hissedilir derecededir. Bir diğer unsur ise zamandır. Tüketiciler içinde bulundukları zamana göre ya satın alma kararı vermekte ya da bu kararı ertelemekte hatta vazgeçebilmektedirler (Deniz, 2011: 253).

\section{Psikolojik Faktörler}

Tüketicilerin mal veya hizmet satın alımındaki temel güdülerinin incelenmesi, pazarlama stratejileri açısından gerekliliğin ötesine geçmiştir. Çünkü insanlar istek ve ihtiyaçları ve bunların karşılanması ile motive olmaktadır. Bilindiği üzere bazı ihtiyaçlar kişinin fiziksel refahını gerektirirken, diğerleri bireyin menfi bakış açısıyla ve diğer insanlarla olan münasebetleriyle ilgilidir. Tam da bu noktada Skinner (1980), psikolojik faktörleri, bireyin şahsiyetinden kaynaklanıp münferit duyguların tezahürü olan ve elbette bireyin davranışını etkileyen güç olarak tanımlamaktadır. Zira söz konusu faktörler, tüketicilerin mal ve hizmetleri "neden” satın aldıkları sorusuna cevap niteliğinde olup, satın almanın altında yatan gayeyi ortaya koymaktadır. Bu bakımdan psikolojik faktörler ürün veya hizmetlerden ziyade ürün veya hizmetlerin hitap ettiği asıl beşeri istek kategorilerini saptamaktadır. Bu itibarla tüketicinin satın alma karar sürecini önemli ölçüde etkileyen psikolojik faktörler; güdülenme, algılama, öğrenme, inanç ve tutumlar ile kişilik olarak sıralanabilir (Skinner, 1980: 157’ den aktaran Mucuk, 2004: 74; Tek, 1990: 140; Perreault, vd., 2013: 115).

Modern pazarlamanın bir boyutu, tüketicilerin ihtiyaçlarını belirleyip bu ihtiyaçlara cevap verebilmek iken, diğer boyutu ihtiyaçların giderilmesi noktasında tüketiciyi güdülemektir. Sıvı ihtiyacının susuzluk dürtüsü yaratması gibi, ihtiyaçlar da tatmin edilmediğinde insanda bir dürtüye yol açar. Öyleyse dürtü, eyleme geçiren güçlü bir uyarıcıdır. Dürtüye yakın bir kavram ise güdüdür. Güdüye uyarılmış ihtiyaç da denilebilir. Ve ihtiyaca dayalı olarak ortaya çıkması, eyleme yön vermesi, tüketicinin gerilimini azaltması ve bir çevre içerisinde oluşması gibi özellikleri vardır. Güdü hakkında verilen bilgilerden yola çıkılarak güdülenme için 
yapılmış teknik tanımlardan bir tanesi güdülenmeyi, enerjiyi belli bir hedef doğrultusunda tüketmek olarak ele almıştır. Bir başka tanımda, kişinin içinde bulunduğu ve bunu bir amaca yöneltecek enerji veren bir kuvvet olduğu şeklinde açıklanmaktadır (Perreault vd., 2013: 115; Çağlar ve Kılıç, 2005: 80; Odabaşı ve Barış, 2014: 130-112; Hatiboğlu, 1993: 40).

Cemalcılar (1999) güdüleri; müşteri olma güdüleri, birincil satın alma güdüleri, seçimli satın alma güdüleri, ussal güdüler ve duygusal güdüler olmak üzere beş başlık altında toplamaktadır. Türü ne olursa olsun bir ihtiyaç hâsıl olduğu takdirde, her tüketici bu ihtiyacı karşılamak için harekete geçer. Fakat genelde her tüketici birbirinden farklı davranmaktadır. Elbette bunun nedeni, kişilerin içinde bulunduğu durum ve şartları farklı biçimlerde algılamalarından ileri gelmektedir. Bu itibarla alg1, bilgi girdilerinin bir anlam çıkarmak amacıyla seçilmesi, sıralanması ve yorumlanmasıdır. O halde, algılama ise, kişinin çevresinde zuhur eden olayları veya uyarıcıları duyu organları vasitasıyla tanımasıdır (Cömert ve Durmaz, 2006: 357; Perreault vd.,2013: 118; Karafakıoğlu, 2006: 86; Cemalcılar, 1999: 58-59).

Süreç olarak yapılan bu tanımlamadan hareketle, algılama süreci tüketicinin dışsal uyarıcılara maruz kalmasıyla başlamaktadır. Uyarıcının tüketici tarafından fark edilmesi esastır. Eğer uyarıcı tüketici tarafından fark edilmeyecek bir vasfa sahipse buna gürültü adı verilmektedir. Söz konusu uyarıcı, tüketici tarafından fark edilmediği takdirde algılamanın ilk basamağı olan dikkat çekme aşaması gerçekleşmediğinden algılamanın vücut bulacağı zemin henüz oluşmamış demektir (Tenekecioğlu, 2009: 76-77; Durmaz, 1999: 61-62). Tüketici davranışlarını etkileyen psikolojik faktörlerden bir diğeri de öğrenmedir. Öğrenme; pekiştirilmiş tekrarlama veya deneyim sonucu davranışta görülen oldukça kalıcı bir değişim olarak tanımlanmaktadır. Zira insanların yaşamlarını sürdürebilmeleri, toplumsal yaşama uyum sağlayabilmeleri ve kendilerini gerçekleştirebilmeleri için sahip oldukları önemli bir davranıştır. İnsan her zaman her yerde bir şeyler öğrendiğinden, insanoğlunun mevcudiyeti devam ettiği müddetçe öğrenme süreci de devam edecektir. Pazarlama penceresinden bakıldığında tüketici davranışlarının tamamı öğrenilmiş davranışlardır (Kim, vd., 1998: 143-144; Li, vd., 2001: 3-6; Osselaer ve Janiszewski, 2001: 202-206; Moore ve Lutz, 2000: 31-36; CunhaJr., vd., 2008: 850-854).

Satın alma davranışına etki eden bir diğer psikolojik faktör ise kişiliktir. Kişilik, bireyi diğerlerinden farklılaştıran ve bireyin çevresiyle genelleştirilmesini sağlayan temel niteliktir. Geçmiş, bugün ve geleceğin oluşturduğu bir sentez şeklinde ifade edilebilir. Bir bireyi diğerinden ayıran davranışlar dizisi olan kişiliğin oluşmasında göz, ten rengi, boy gibi birçok genetik özellikle, sosyal sınıf, aile, kitle iletişim araçları, grup üyeliği gibi çevresel etmenler rol oynamaktadır. Devamında, kişiliğin ön plana çıkan üç önemli özelliği; kişisel farklılıklar, kişiliğin devamlı, dengeli ve değişebilir olmasıdır. Bu açıklamaların ötesinde, bireyin kişiliğini belirleyen en önemli faktör ise kalıtımdır. Aileden gelen genetik özellikler, kesin olarak kişilik tipini belirlemese de, geliştirilecek kişilikte baskın bir özellik sergilemektedir (Altunışık, vd., 2001: 63; Durmaz, 1999: 60-61; Milli Eğitim Bakanlığı, 2012: 27).

Nihayet, satın alma davranışını etkileyen ve öğrenme aktiviteleri sonucu kazanılan son faktör ise tutum ve inançlardır. İnanç; bir kimsenin tanımlayıcı fikirleri ile dış faktörler veya kendi deneyimleri sonucunda benimsediği düşüncedir. İnanç ile güven duygusu arasında sıkı bir ilinti söz konusu olup, insanlar hayatlarını bu inançlara bağlı kalarak idame ettirirler. Üreticilerin üretim faaliyetiyle ortaya koymuş oldukları imaj hakkında şayet bazı yanlış inançlar varsa ve bu durum satın almada sıkıntı yaratıyorsa bu sorun derhal düzeltilmelidir. Buna karşılık tutum, kişinin kimi nesnelere ya da düşüncelere karşı olumlu veya olumsuz bilişsel değerlemeleri, duyguları ve eğilimleridir. Bir zincirin halkaları misali, tutum, düşünce süreci ve duyguları kapsarken, inançlar da davranışları etkilemektedir. Ayrıca algıyı etkileyebilme ve algıda bozukluklar yaratabilme özelliği ile de algı üzerinde oldukça etkilidir (Çekmecelioğlu, 2006: 153-159; Kotler, 2000b: 174; Cemalc1lar, 1999: 60). 


\section{Tüketici Satın Alma Karar Süreci}

Satın alma eyleminde bulunan insanlar benzer davranışlar mı sergiler sorusunun cevabını anlamada satın alma sürecinin değerlendirilmesi büyük destek sağlayacaktır. Bu perspektifle tüketici davranışlarındaki temel varsayımlardan biri, pek çok satın almanın bir karar süreci vasıtasıyla belirli bir formata kavuştuğu yönündedir (Odabaşı, 2012: 159-160).

Karardan söz edebilmek için tüketicinin ortaya çıkan ihtiyacı bertaraf etmek adına iki ürün arasında seçim yapması gerekmektedir. Tercih sırasında belirlenen değerlendirme ölçütleri, tüketicinin her bir seçeneğin sonuçlarının kendisinin hedefleri doğrultusunda tahminine imkân sağlamaktadır. Karar verme sürecinde dış kaynaklardan elde edilen ya da kişinin zihnindeki bilgilerle, kişi belirli değerlendirmeler sonucu alternatiflerden birini seçer. Bu sıralanan unsurlar aynı zamanda karar verme sürecinin başlıca varsayımlarını oluşturmaktadır. Ve böylece satın alma eylemini ifa eden tüketici karar vermiş olur. Ancak şöyle bir durum söz konusu ki, kararın alınmasıyla kararın uygulanması arasında daima farklar oluşur. Neredeyse hiçbir karar yoktur ki, olduğu gibi icra edilsin. Bu açıklamalardan hareketle satın alma kararının belirli adımlardan oluştuğu anlaşılmaktadır. Öyleyse tüketici satın alma karar süreci satın alım öncesi, satın alım sırasındaki aşamalar ve satın alımın sonrasına ait tüm prosesi içine almaktadır. (Nazik, vd., 2014: 21-25; Özcan, 2010: 30; http://www.temelak soy.com/?s=adama+ ve+duruma+g\%C3 \%B6re, E.T. 03.09.2015).

Tüketici satın alma karar süreci şu beş basamaktan oluşur: (Tenekecioğlu, 2009: 78-82; Odabaş1, 2012: 160-172; Tek, 1990: 147-153): İhtiyacın ortaya çıkması, alternatiflerin tespit edilmesi, alternatiflerin değerlendirilmesi, satın alma kararı ve satın alma sonrası değerlendirmedir.

\section{ARAŞTIRMA LITERATÜRÜ}

Satın alma davranışı pek çok alanda araştırma konusu olmakla birlikte özellikle pazarlama alanında hatırı sayılır nüfuz elde etmiştir. Ve bu araştırmalar iş profesyonelleri ve akademisyenler tarafindan yapılmaya devam etmektedir.

Güven ve Davudov (2012), yaptıkları çalışmayla Türkiye ve Azerbaycan' 1 otomobil tüketicilerinin otomobil satın alımına etki eden faktörlerin belirlenmesi ve karşılaştııılmasını amaçlamışlardır. Bu amaca yönelik olarak Türkiye ve Azerbaycan' 11 otomobil sahipleri örneklem olarak seçilmiştir. 589 kişiye uygulanan anketle, Türkiye ve Azerbaycan uyruklu otomobil kullanıcılarının otomobil satın alımına etki eden faktörler belirlenmiş ve karşılaştırma yapmak amacıyla birbirinden bağımsız iki örneklemin ortalamaları arasındaki farkın hangi yönde olduğu test edilmiştir. Bu farkın test edilmesinde "Bağımsız iki grup arası farkların testi (Independest Samples " $t$ " test)" uygulanmış ve hipotezler t testi ile denenmiştir. Araştırma sonucunda iki ülke katılımcıları arasında otomobilin üretim yılı, üretildiği ülke, motor gücü, fiyatı, yakıt tüketimi, servis ve yedek parçaları ve verginin düşük olması konularında belirli farklılıklar gözlemlenmiştir. Diğer taraftan, otomobilin çevreye az zarar vermesi, dış görünümü, kolay satılabilme imkânı, güvenli olması, markası, dayanıklılı̆̆ı, imaj ve renk faktörlerine verilen önem açısından anlamlı farklılıklar bulunmamıştır.

Arslan (2003), otomobil alımında tüketici davranışlarını etkileyen faktörler konulu çalışmasında, tüketicinin hangi pazarlama bileşenleri veya markalardan tatmin olduğunu ve bu tatmini sağlamak için hangi marka ve modelleri nasıl ve neye göre seçtiğini araştırmıştır. Bunu belirlemek amacıyla otomobil pazarlamasında müşteri odaklı yaklaşım anlayışının sağlayacağı yararlar üzerinde durmuştur. Araştırma sonucuna göre, otomobil satın alma kararında marka seçimini aile unsuru belirli ölçüde etkilemektedir. Bu etki, aile yapısına ve ailenin bağlılık derecesine göre değişiklik arz etmektedir. Sosyal sınıf, özellikle gelir, meslek, eğitim gibi faktörler de otomobil satın alımını etkileyen önemli faktörler arasında sayılmaktadır.

Niestroj (2014), Polonya' da otomobil pazarında tüketici satın alma davranışının tipolojisini incelemiştir. Araştırma örnekleminin yapısı sadece cinsiyet ve yaş açısından çeşitlilik arz etmektedir. Araştırmada cinsiyet ve yaş, otomobil müşterilerinin davranışlarını önemli derecede farklılaştıran demografik özellikler olarak 
kabul edilmiştir. Çalışma çevrimiçi anket yoluyla gerçekleştirilmiştir. Web sitesi 934 ziyaretçi tarafından ziyaret edilmiştir. Anketin \%70.5' i doldurulmuştur. Veriler, 600 ankete dayanılarak analiz edilmiştir. Sonuç olarak, tipolojik kriterler; demografik, psikolojik ve sosyo-ekonomik grupları, eksiksiz bir pazar segmentasyonu için yeterli bir kriter olarak kullanılabilmiştir ve bu nedenle, tamamlayıcı mallar ve hizmet portföyü otomobil pazar portföyü için bir yol haritası oluşturmuştur. Bu analiz özellikle rekabet analizi ve iş ortamı ile ilgili araştırma ile birleştiğinde, genel olarak pazarlama stratejisi hakkında daha iyi kararlar almaya olanak tanımıştır.

Ruhlusaraç ve Nakip (2016), akademisyenlerin otomobil satın alım tercihlerini etkileyen faktörleri araştırmışlardır. Araştırma fakültelerde farklı alanlarda görev yapan 135 akademisyen üzerinde gerçekleştirilmiştir. Araştırmada anket tekniği kullanılmış ve hipotezlere ayırma analizi ile Wilks' Lambda testi kontrolü yapılmıştır. Sonuç olarak, cinsiyet ve gelir ile marka tercihi arasında ve gelir ile yaş itibariyle otomobil satın alım sıklığı arasında fark olduğu tespit edilmiştir. Demografik faktörlerden ise, gelirin çok etkili olduğu belirlenmiştir.

Saydan (2008), çalışmasında, otomobil tercihinde tüketicileri harekete geçiren rasyonel ve hedonik yararların neler olduğunu ve güdüleyici unsurlar olarak kabul edilen bu yararlara atfedilen önem düzeyinin tüketicilerin demografik özelliklerine göre değişiklik arz edip etmediğini belirlemiştir. Çalışma Van İlinde ve 236 kişilik bir örneklemle yürütülmüştür. Veriler Anova ve t testi ile incelenmiştir. Elde edilen verilere göre, tüketicileri harekete geçiren rasyonel ve hedonik yararlar, demografik faktörlere göre istatistiki açıdan anlamlı farkl11ıklar göstermiştir.

Yayar vd. (2015), otomobil sahipliğini etkileyen faktörleri incelemiştir. Bu çerçevede Tokat İli merkezinde 438 aile üzerinde yapılan araştırmayla otomobil sahipliğini belirleyen sosyo-ekonomik ve demografik faktörlerin neler olduğu ve bu faktörlerin tüketicilerin otomobil sahibi olup olmamalarını etkileme düzeyleri belirlenmiştir. Çalışmada BinaryLogit Modeli uygulanmıştır. Araştırma sonunda aile reisinin erkek, esnaf, yüksek gelirli, ev sahibi ve kredi kartının bulunması değişkenleri istatistiksel olarak anlamlı bulunup otomobil sahipliğini olumlu yönde etkilemiştir.

Barley (2015), iki otomobil bayiinde iki yıl boyunca toplanan etnografik verilere dayanan çalışmasıyla, rol teorisi ve satış karşılaştırmalarının dramaturjik analizi kullanılarak internetin otomobil satıcısı ve müşterileri arasındaki ilişkiyi nasıl değiştirdiğini göstermiştir. Veriler Kuzey Kaliforniya' da 18 aydan fazla bir sürede iki otomobil satıcısından toplanmıştır. Satıcının biri Chevrolet satarken diğeri Toyota satmaktadır. Yapılan çalışma doğrultusunda elde edilen bulgulara göre, bilgisayar aracılı iletişim yüz yüze ve uzaktan yapılan iletişime göre daha etkili olduğu sonucuna ulaşılmıştır.

Arıtan ve Akyüz (2015), yaptıkları çalışmayla tüketicilerin otomobil markalarına yönelik marka sadakatleri ve tercihlerini araştırmışlardır. Araştırma evrenini Gümüşhane il merkezinde ikamet eden 4765 otomobil sahibi oluşturmuştur. Araştırmada Markov Zinciri Analizi Yöntemi kullanılmıştır. Sonuç olarak en yüksek marka bağımlılığı Audi, Mercedes ve Opel markalarında görülmüştür. Bayan katılımcılar Volkswagen, Renault ve Peugeot markalarını tercih ederken, erkek katılımcılar Tofaş, Fiat, Renault ve Ford markalarını tercih etmişlerdir. Düşük gelirli katılımcılar Tofaş ve Renault markalarını, orta gelir düzeyine sahip katılımcılar Tofaş, Fiat, Renault ve Ford markalarını ve üst gelir seviyesine sahip katılımcılar ise, Volkswagen,Toyota, Skoda, Opel, Nissan, Honda ve Citroen markalarını tercih etmişlerdir.

Shende (2014) çalışmasıyla, otomobil tüketici davranışı alanındaki araştırmaların analizini sunmuştur. Çalışmanın amacı, müşterilerin otomobillerin belirli segmentleri için tercihlerini etkileyen faktörlerin belirlenmesidir. Bu çerçevede Hint otomobil endüstrisindeki tüm segmentler incelenmiş ve araç satın alımının esas faktörü olan harcanabilir gelir olduğu, her segmentte önceliğe sahip olduğu bulunmuştur. Para, emniyet 
ve sürüş konforu değerlerinin müşteri gereksinimi bakımından en üst seviyede olduğu tespit edilmiş, müşterilerin algıladıkları kalitenin ise esas olarak marka imajına bağlı olduğu görülmüştür.

Köksal ve Türedi (2014), tüketici otomobil tercihinde etkili olan bilgi ve iletişim kanalları üzerine bir inceleme konulu çalışmalarıyla, otomobil tercihinde etkili olan bilgi ve iletişim kanallarının tüketiciler açısından önem düzeylerinin belirlenmesini ve hangilerinin daha etkili olduğunun ortaya konulmasını amaçlamışlardır. Bu kapsamda Antalya, Isparta ve Burdur şehirlerinde 477 kişi üzerinde toplanan veriler yapısal eşitlik modellemesi ile analiz edilmiştir. Böylece iletişim kanalları kullanımının marka tercihi üzerindeki etkileri analiz edilmiştir. Araştırma neticesinde elde edilen bulgulara göre otomobil marka tercihine doğrudan etki eden unsurların kişisel deneyim, otomobil bayileri, galeriler ve satışçllar olduğu tespit edilirken, geleneksel medya, ağızdan ağıza iletişim ve internetin de dolaylı bir etkiye sahip olduğu görülmüştür.

Raj vd. (2013), ekonomi segmentinde SUV (Sport Utility Vehicle) ve MUV (Multi Purpose Vehicle)' ların marka tercihlerini etkileyen faktörleri incelemişlerdir. Verilerin toplanmasında anket yöntemi kullanılmıştır. Verileri anlamlı kılmak için betimsel analiz kullanılmış ve müşteri tercihini etkileyen faktörlerin belirlenmesinde faktör analizi kullanılmıştır. Çalışma bulguları ışığında, belirli bir markanın tercihi, ürün güvenilirliği, parasal faktör, popüler çekicilik, sunulan fiyat-dışı promosyonların sıklı̆̆ı, güvenilirlik ve müşteri duygusu veya markaya yönelik ilişki olmak üzere altı faktör ile açıklanmıştır. Bu durum, pazarlamacıların, otomobil pazarının SUV (Sport Utility Vehicle) segmentinde ürün yeniliklerini hazırlarken bu faktörleri göz önüne almaya ihtiyaç duymaları bakımından önem arz etmektedir.

\section{ARAŞTIRMA METODOLOJISİ}

Çalışmanın bu bölümünde, Selçuk Üniversitesi akademik personelinin araç satın alma davranışlarını incelemek üzere araştırmanın amacı, yöntemi, örneklemi ve bulguları hakkında bilgi verilecektir. Ayrıca, araştırmada elde edilen sonuçların istatistiki bakımdan anlamlı olup olmadıkları değerlendirilecek ve sonuçlar literatür bağlamında tartışılacaktır.

\section{Araştırmanın Amacı}

$\mathrm{Bu}$ çalışmanın temel amacı "akademisyenlerin araç satın alma davranışlarının" incelenmesidir. Otomobil, insanların ulaşım gibi temel ihtiyaçlarını karşılamanın yanı sıra sosyal ve psikolojik ihtiyaçlarına da cevap verebilmektedir. Akademisyenler ise farklı statülere, farklı gelir düzeylerine sahip olduklarından aynı zamanda toplumu etkileme potansiyelleri dolayısıyla araştırma, akademisyenler üzerinde yürütülmüştür.

\section{Araştırmanın Yöntemi ve Örneklem}

Akademisyenlerin araç satın alma davranışlarını incelemeye yönelik yapılan bu araştırmada verilerin toplanmasında anket yönteminden yararlanılmıştır.

Hazırlanan anket formundaki soruların belirlenmesinde ilgili literatür ve bu konuda daha önce yapılan benzer çalışmalar dikkate alınmıştır. Anket tasarımı iki bölümden oluşmaktadır. Birinci bölümde anket katılımcılarının araç satın alma ile ilgili özelliklerini belirlemeye yönelik sorular, ikinci bölümde ise tüketici memnuniyetini belirlemeye yönelik sorular sorulmuştur. Anketteki ölçekler oluşturulurken Dongyan ve Xuan tarafindan 2008 yılında tamamlanan "Pekin'de Otomobil Satın Alma Davranışları: Ampirik Bir Araştırma" isimli tezden faydalanılmıştır. Anketin ilk tasarımının ardından anket 35 akademisyene cevaplatılarak hem anketin anlaşılabilirliği, cevaplama süresi vb. faktörler araştırılmış hem de çalışmaya ilişkin pilot çalışma yapılarak anketin nihai haline karar verilmiştir. Pilot araştırmaya katılan kişiler hem akademisyen olmaları hem de sosyal bilimlerde araştırma yöntemleri konusunda çalışmaları yönüyle özel olarak seçilmiştir.

Pilot araştırmanın ardından nihai şekli verilen anket formları Selçuk Üniversitesi' nde görev yapan akademisyenlerle rastgele örneklem seçimi yoluyla ve yüz yüze görüşülerek yapılmıştır. Bir hafta süreyle uygulanan anketler sonucunda toplamda 135 anket cevaplanmış fakat eksik ve/veya aynı cevaplı olan, arabası olmayan kullanıcılara ait 8 anket değerlendirmeye alınmamış, bu nedenle 127 anket dikkate alınmıştır. Evren 
büyüklüğü dikkate alındığında \%10 örneklem hatası ile ulaşılan anket sayısı istatistiksel olarak yeterli bulunmuştur.

Elde edilen veriler "SPSS (Statistical Package for Social Sciences - Sosyal Bilimler için İstatistik Paketi)/Windows 2.0 Sürümü" istatistik analiz programına uygun olarak kodlanmış ve çalışmanın amacına uygun testler analiz edilmiştir.

\section{ARAŞTIRMANIN BULGULARI}

\section{Akademisyenlerin Araç Satın Alma İle İlgili Özellikleri}

Araştırma kapsamında akademisyenlere araştırma ile ilgili olarak gelir, araç kullanım amacı, otomobil tercihi, otomobil fiyatı, otomobil markası, satın almada kullanılan bilgi kaynakları, satın alma kararı ve eylemi arasında geçen süre, satın alma kararının çevre ile paylaşılma durumu, bayi ziyareti, satın alma kararındaki etki, satın alma sürecindeki etki ve otomobili kullanan kişi olmak üzere toplam 11 soru yöneltilmiştir. Akademisyenlerin satın alma ile ilgili özelliklerine ilişkin değerlendirmeler aşağıda verilmiştir.

Tablo 1: Araştırmaya Katılan Akademisyenlerin Aylık Toplam Gelir Durumu

\begin{tabular}{|c|c|c|}
\hline & Frekans & $\%$ \\
\hline 5000 TL'den az & 30 & 23,6 \\
\hline 5000-9999 TL & 80 & 63,0 \\
\hline $10000-19999$ TL & 17 & 13,4 \\
\hline Toplam & 127 & 100,0 \\
\hline
\end{tabular}

Akademisyenlerin \%23,6' s1 5000 TL' den az, \%63' ü 5000-9999 TL, \%13,4' ü ise 10000-19999 TL aylık toplam gelire sahiptir.

Tablo 2: Araştırmaya Katılan Akademisyenlerin Günlük Araç Kullanım Amacı

\begin{tabular}{|c|c|c|}
\hline & Frekans & $\%$ \\
\hline İş Amacıyla & 30 & 23,6 \\
\hline Kişisel & 75 & 59,1 \\
\hline Aile İçin & 22 & 17,3 \\
\hline Toplam & 127 & 100,0 \\
\hline
\end{tabular}

Akademisyenlerin \%23,6' sı iş amacıyla, \%59,1' i kişisel, \%17,3' ü aile için sıklıkla araç kullanmaktadır.

Tablo 3: Araştırmaya Katılan Akademisyenlerin Araç Tercihi

\begin{tabular}{|c|c|c|}
\hline & Frekans & $\%$ \\
\hline Sifir Km & 43 & 33,9 \\
\hline İkinci El & 45 & 35,4 \\
\hline Fark Etmez & 39 & 30,7 \\
\hline Toplam & 127 & 100,0 \\
\hline
\end{tabular}

Akademisyenlerin \%33,9' u sıfır, \%35,4' ü ikinci el araç kullanmayı tercih ederken \%30,7' si her iki tür aracı da alabileceklerini belirtmişlerdir. 
Tablo 4: Araştırmaya Katılan Akademisyenlerin Araçlarının Fiyatları

\begin{tabular}{|c|c|c|}
\hline & Frekans & $\%$ \\
\hline 20000TL'den az & 8 & 6,3 \\
\hline 20000-49999 TL & 79 & 62,2 \\
\hline $50000-99999 \mathrm{TL}$ & 35 & 27,6 \\
\hline $100000-149999 \mathrm{TL}$ & 3 & 2,4 \\
\hline $150000-249999 \mathrm{TL}$ & 2 & 1,6 \\
\hline Toplam & 127 & 100,0 \\
\hline
\end{tabular}

Akademisyenlerin kullandıkları araçların \%6,3’ ü 20000TL' den az, \%62,2’ si 20000-49999 TL, \%27,6' s1 50000-99999 TL, \%2,4' ü 100000-149999 TL, \%1,6’ s1 150000-249999 TL fiyat aralıklarındadır.

Tablo 5: Araştırmaya Katılan Akademisyenlerin Araçlarının Markası

\begin{tabular}{|c|c|c|}
\hline & Frekans & $\%$ \\
\hline Audi & 6 & 4,7 \\
\hline Volkswagen & 18 & 14,2 \\
\hline Skoda & 3 & 2,4 \\
\hline Seat & 3 & 2,4 \\
\hline BMW & 3 & 2,4 \\
\hline Mercedes & 5 & 3,9 \\
\hline Volvo & 6 & 4,7 \\
\hline Ford & 13 & 10,2 \\
\hline Fiat & 9 & 7,1 \\
\hline Chevrolet & 1 & 0,8 \\
\hline Citroen & 4 & 3,1 \\
\hline Renault & 10 & 7,9 \\
\hline Peugeot & 6 & 4,7 \\
\hline Toyota & 7 & 5,5 \\
\hline Nissan & 2 & 1,6 \\
\hline Honda & 3 & 2,4 \\
\hline Mazda & 1 & 0,8 \\
\hline Hyundai & 4 & 3,1 \\
\hline Kia & 1 & 0,8 \\
\hline Opel & 18 & 14,2 \\
\hline Diğer & 4 & 3,1 \\
\hline Toplam & 127 & 100,0 \\
\hline
\end{tabular}

Akademisyenlerin 20 farklı markada araç kullandıkları ve bu markalar içerisinde de en çok Volkswagen, Opel ve Ford markalarını tercih ettikleri görülmüştür.

Tablo 6: Araştırmaya Katılan Akademisyenlerin Satın Almada Kullandıkları Bilgi Kaynakları

\begin{tabular}{|c|c|c|}
\hline & Frekans & $\%$ \\
\hline Broşür & 17 & 13,4 \\
\hline Bayi Satış Personeli & 36 & 28,3 \\
\hline Otomobil Dergileri & 16 & 12,6 \\
\hline Arkadaşlar ve Aile Bireyleri & 62 & 48,8 \\
\hline Gazete Reklamları & 1 & 0,8 \\
\hline TV Reklamları & 17 & 13,4 \\
\hline Otomobil Fuarları & 8 & 6,3 \\
\hline Web/İnternet Araştırması & 95 & 74,8 \\
\hline Diğer & 9 & 7 \\
\hline
\end{tabular}


Akademisyenlerin en çok \%74,8 oranında web/internet araştırması, \%48,8 oranında arkadaşlar ve aile bireyleri ve $\% 28,3$ oranında bayi satış personeli yoluyla araç satın alırken bilgi topladıkları görülmektedir.

Tablo 7: Araştırmaya Katılan Akademisyenlerin Satın Alma Kararı ve Eylemi Arasında Geçen Süre

\begin{tabular}{|c|c|c|}
\hline & Frekans & $\%$ \\
\hline 2 haftadan az & 17 & 13,4 \\
\hline 2 hafta-1 ay & 33 & 26,0 \\
\hline 1-3 ay & 52 & 40,9 \\
\hline 3-6 ay & 11 & 8,7 \\
\hline 6 aydan fazla & 14 & 11,0 \\
\hline Toplam & 127 & 100,0 \\
\hline
\end{tabular}

Akademisyenlerin \%13,4' ü 2 haftadan az, \%26' s1 2 hafta-1 ay, \%40,9' u 1-3 ay, \%8,7' si 3-6 ay, \%11' i 6 aydan fazla sürede karar verip araç satın alma işlemini tamamlamışlardır.

Tablo 8: Araştırmaya Katılan Akademisyenlerin Satın Alma Kararını Çevre İle Paylaşma Durumu

\begin{tabular}{|c|c|c|}
\hline & Frekans & $\%$ \\
\hline Evet & 117 & 92,1 \\
\hline Hayır & 10 & 7,9 \\
\hline Toplam & 127 & 100,0 \\
\hline
\end{tabular}

Akademisyenlerin \%92,1' i araç satın alma kararını çevreleriyle konuşmuşlardır.

Tablo 9: Araştırmaya Katılan Akademisyenlerin Bayi Ziyareti

\begin{tabular}{|c|c|c|}
\hline & Frekans & $\%$ \\
\hline Hiç Ziyaret Etmedim & 15 & 11,8 \\
\hline 1-3 Aras1 & 65 & 51,2 \\
\hline 3-5 Aras1 & 32 & 25,2 \\
\hline 5-7 Aras1 & 10 & 7,9 \\
\hline 7'den Fazla & 5 & 3,9 \\
\hline Toplam & 127 & 100,0 \\
\hline
\end{tabular}

Akademisyenlerin \%51,2' si 1-3 kez, \%25,2' si 3-5 kez, \%7,9' u 5-7 kez, \%3,9' u 7' den fazla kez otomobil bayisini ziyaret etmiş, \%11,8' i ise hiç bayi ziyaretinde bulunmamıştır.

Tablo 10: Araştırmaya Katılan Akademisyenlerin Satın Alma Kararındaki Etki Düzeyi

\begin{tabular}{|c|c|c|}
\hline & Frekans & $\%$ \\
\hline Tek Karar Verici Benim & 35 & 27,6 \\
\hline Karar Vericilerden Biriyim ve Belirleyici Rolüm Var & 84 & 66,1 \\
\hline Karar Vericilerden Biriyim ve Belirleyici Rolüm Yok & 6 & 4,7 \\
\hline Tamamen Diğerleri Karar Verici & 2 & 1,6 \\
\hline Toplam & 127 & 100,0 \\
\hline
\end{tabular}

Akademisyenlerin \%27,6' s1 tek karar verici, \%66,1' i belirleyici rolde, \%4,7' si karar vericilerden biri, $\% 1,6$ ' s1 ise karar sürecinde pasif rol almaktadırlar. 
Tablo 11: Araştırmaya Katılan Akademisyenlerin Araç Kullanma Durumu

\begin{tabular}{|c|c|c|}
\hline & Frekans & $\%$ \\
\hline Kendim & 104 & 81,9 \\
\hline Eşim & 18 & 14,2 \\
\hline Çocuğum & 1 & 0,8 \\
\hline Diğer Aile Üyeleri & 4 & 3,1 \\
\hline Toplam & 127 & 100,0 \\
\hline
\end{tabular}

Akademisyenlerin kendi aracını \%81,9' u kendisi, \%14,2' si eşi, \%0,8' i çocuğu, \%3,1' i de diğer aile üyelerinin kullandıklarını belirtmişlerdir.

Tablo 12:Araştırmaya Katılan Akademisyenlerin Satın Alma Sürecindeki Etki Düzeyi

\begin{tabular}{|c|c|c|}
\hline & Frekans & $\%$ \\
\hline Yeni Otomobil Satın Alma Kararı & 78 & 61,4 \\
\hline Bütçe Belirleme & 74 & 58,3 \\
\hline Marka ve Modellerin İlk Tercihleri & 55 & 43,3 \\
\hline Otomobil Bayisi ile İrtibat Kurmak & 30 & 23,6 \\
\hline Marka ve Modeller Hakkında Bilgi Toplama & 64 & 50,4 \\
\hline Bayi Ziyaretleri & 29 & 22,8 \\
\hline Test Sürüşü & 36 & 28,3 \\
\hline Fiyat Pazarlığı & 50 & 39,4 \\
\hline Marka ve Model Üzerinde Nihai Karar & 64 & 50,4 \\
\hline
\end{tabular}

Akademisyenler en çok satın alma sürecinde $\% 61,4$ oranında yeni otomobil satın alma kararı, \%58,3 oranında bütçe belirleme, \%50,4 oranında marka ve modeller hakkında bilgi toplama ile marka ve model üzerinde nihai karar süreçlerine dâhil olmuşlardır.

\section{Fark Testleri}

\section{Satın Alınan Otomobilin Fiyatına Göre Genel Memnuniyet Düzeyine İlişsin Fark Testi}

Tek Yönlü Anova testi yapılmadan önce grupların varyanslarının eşitliği Levene testi ile test edilmelidir.

$\mathrm{H}_{0}$ : Genel memnuniyet düzeyine göre satın alınan otomobil fiyatı değişkeni gruplarının varyansları eşittir.

$\mathrm{H}_{1}$ : Genel memnuniyet düzeyine göre satın alınan otomobil fiyatı değişkeni gruplarının varyansları eşit değildir.

Tablo 13: Satın Alınan Otomobil Fiyatına Göre Varyansların Eşitliği Testi

\begin{tabular}{|l|c|c|}
\hline & $\begin{array}{c}\text { Levene } \\
\text { İstatistiği }\end{array}$ & $\begin{array}{c}\text { Anlamlılık } \\
\text { Düzeyi }\end{array}$ \\
\hline Genel Memnuniyet Düzeyi & 2,365 & 0,057 \\
\hline
\end{tabular}

Levene testinin sonucuna göre genel memnuniyet düzeyi değişkeni için grupların eşitliği söz konusudur (p: 0,057>0,05). Bu sonuçlara göre tek yönlü ANOVA testinin ön şartı sağlanmıştır.

H0: Satın alınan otomobil fiyatı gruplarının genel memnuniyet düzeyine katılım değerlerinin ortalamaları eşittir.

H1: Satın alınan otomobil fiyatı gruplarının genel memnuniyet düzeyine katılım değerlerinin ortalamalarının en az bir tanesi farklıdır.

Tablo 14: Satın Alınan Otomobil Fiyatına Göre Anova Testi

\begin{tabular}{|l|c|c|}
\hline & F & p \\
\hline Genel Memnuniyet Düzeyi & 1,945 & 0,107 \\
\hline
\end{tabular}


Tablo 14'e göre p>0,05 olduğu için H0 hipotezi kabul edilir. Yani satın alınan otomobil fiyatına göre genel memnuniyet düzeyi farklılık göstermemektedir.

\section{Satın Almadaki Etki Düzeyine Göre Genel Memnuniyet Düzeyine İlişkin Fark Testi}

Tek Yönlü Anova testi yapılmadan önce grupların varyanslarının eşitliği Levene testi ile test edilmelidir. $\mathrm{H}_{0}$ : Genel memnuniyet düzeyine göre satın almadaki etki düzeyi değişkeni gruplarının varyansları eşittir.

$\mathrm{H}_{1}$ : Genel memnuniyet düzeyine göre satın almadaki etki düzeyi değişkeni gruplarının varyansları eşit değildir.

Tablo 15: Satın Almadaki Etki Düzeyine Göre Varyansların Eşitliği Testi

\begin{tabular}{|l|c|c|}
\hline & $\begin{array}{c}\text { Levene } \\
\text { Istatistiği }\end{array}$ & $\begin{array}{c}\text { Anlamlılık } \\
\text { Düzeyi }\end{array}$ \\
\hline Genel Memnuniyet Düzeyi & 0,851 & 0,468 \\
\hline
\end{tabular}

Levene testinin sonucuna göre genel memnuniyet düzeyi değişkeni için grupların eşitliği söz konusudur (p: $0,468>0,05)$. Bu sonuçlara göre tek yönlü ANOVA testinin ön şartı sağlanmıştır.

H0: Satın almadaki etki gruplarının genel memnuniyet düzeyine katılım değerlerinin ortalamaları eşittir.

H1: Satın almadaki etki gruplarının genel memnuniyet düzeyine katılım değerlerinin ortalamalarının en az bir tanesi farklıdır.

Tablo 16: Satın Almadaki Etki Düzeyine Göre Anova Testi

\begin{tabular}{|l|c|c|}
\hline & F & p \\
\hline Genel Memnuniyet Düzeyi & 3,611 & 0,015 \\
\hline
\end{tabular}

Tablo 16' e göre $\mathrm{p}<0,05$ olduğu için H0 hipotezi reddedilir.Yani satın alınan otomobil fiyatına göre genel memnuniyet düzeyi farklılık göstermektedir. Scheffe ve Tukey testi sonuçlarına göre "tek karar verici benim", "karar vericilerden biriyim ve belirleyici rolüm yok", grupları, "karar vericilerden biriyim ve belirleyici rolüm var" ve "karar vericilerden biriyim ve belirleyici rolüm yok" grupları arasında anlamlı farklılıklar görülmüştür. $\mathrm{Bu}$ gruplar arasında tek karar verici olan kişilerin karar vermede belirleyici rolü olmayan kişilere göre, karar vermede belirleyici rolü olan kişilerin belirleyici rolü olmayan kişilere göre genel memnuniyet düzeylerinin daha yüksek olduğu görülmüştür.

\section{Regresyon Analizi}

\section{Parasal Değer, Dış Dizayn/Boyut Boyutları-Genel Memnuniyet Düzeyi İliş̧kisi}

Çalışmanın bu bölümünde parasal değer ve dış dizayn/boyut değişkenlerinin genel memnuniyet düzeyi üzerinde etkisi olup olmadığı incelenmiştir. Bu kapsamda parasal değer ve dış dizayn/boyut değişkenlerinin bağımsız değişken, genel memnuniyet düzeyinin de bağımlı değişken olarak ele alındığı çoklu regresyon modeli test edilmiştir.

H0: Parasal değer ve dış dizayn/boyut değişkenleri genel memnuniyet düzeyi değişkenini açıklamada istatistiksel olarak anlamsızdır.

H1: Parasal değer ve diş dizayn/boyut değişkenleri genel memnuniyet düzeyi değişkenini açılamada istatistiksel olarak anlamlıdır. 
Tablo 17: Parasal Değer, Dış Dizayn/Boyut Boyutları-Genel Memnuniyet Düzeyi İlişkisi Anova Tablosu

\begin{tabular}{|c|c|c|c|c|c|}
\hline & Kareler Toplamı & Serbestlik Derecesi (df) & Kareler Ortalaması & F & p \\
\hline Regresyon & 28,722 & 2 & 14,361 & 43,556 &, $000(\mathrm{a})$ \\
\hline Artık & 40,884 & 124 & 0,33 & \\
\hline Toplam & 69,606 & 126 & & \\
\hline \multicolumn{4}{|r|}{ a Bağımsız Değişkenler: (Sabit), Parasal Değer, Diş Dizayn } \\
\hline \multicolumn{5}{|r|}{ b Bağımlı Değişken: Genel Memnuniyet Düzeyi } \\
\hline
\end{tabular}

Tablo 17' deki ANOVA tablosu incelendiğinde, $\mathrm{F}$ değeri 43,556 ve $\mathrm{p}$ değeri 0,00 olduğundan $\mathrm{H}_{0}$ hipotezinin reddine karar verilir. Buna göre oluşturulan regresyon modeli istatistiksel olarak anlamlıdır. Yani genel memnuniyet düzeyi değişkenini parasal değer ve dış dizayn/boyut değişkenlerinden en az biri ile tahmin etmek istatistiksel olarak mümkündür.

Tablo 18: Parasal Değer, Dış Dizayn/Boyut Boyutları-Genel Memnuniyet Düzeyi İliş̧kisi Regresyon Katsayıları

\begin{tabular}{|c|c|c|c|c|c|c|c|}
\hline & \multicolumn{2}{|c|}{$\begin{array}{c}\text { Standardize } \\
\text { Edilmemiş Katsayılar } \\
\end{array}$} & \multirow{2}{*}{$\begin{array}{c}\text { Standardize } \\
\text { Katsayılar } \\
\text { Beta }\end{array}$} & \multirow[t]{2}{*}{$\mathbf{t}$} & \multirow{2}{*}{$\mathbf{p}$} & \multicolumn{2}{|c|}{$\begin{array}{l}\text { Çoklu Bağıntı } \\
\text { İstatistikleri }\end{array}$} \\
\hline & B & Std. Hata & & & & B & VIF \\
\hline (Sabit) & 1,246 & 0,34 & & 3,668 & 0 & & \\
\hline Parasal değer & 0,375 & 0,074 & 0,372 & 5,039 & 0 & 0,869 & 1,15 \\
\hline $\begin{array}{c}\text { Diş } \\
\text { dizayn/boyut }\end{array}$ & 0,38 & 0,069 & 0,406 & 5,502 & 0 & 0,869 & 1,15 \\
\hline
\end{tabular}

Tablo 18 incelendiğinde parasal değer ve dış dizayn değişkenleri için p değerleri 0,05 ' ten küçük olduğu için bu değişkenler genel memnuniyet düzeyi değişkenini açıklamada istatistiksel olarak anlamlıdır. Ayrıca tablo 18'deki VIF değerlerinin 10 değerinden küçük olduğu, dolayısıyla değişkenler arasında çoklu bağlantı olmadığına karar verilebilir. Buna göre bahsi geçen regresyon modeli şu şekilde kurulabilir:

$$
\text { Genel memnuniyet düzeyi }=1,246+0,375 \text { Parasal değer }+0,38 \text { Dış dizayn/boyut }
$$

Tablo 19: Parasal Değer, Dış Dizayn/Boyut Boyutları-Genel Memnuniyet Düzeyi İlişkisi Regresyon Model Özeti

\begin{tabular}{|c|l|l|l|}
\hline $\mathbf{R}$ & \multicolumn{1}{|c|}{$\mathbf{R}^{\mathbf{2}}$} & \multicolumn{1}{|c|}{ Düzeltilmiş $\mathbf{R}^{\mathbf{2}}$} & Tahminin Std. Hatası \\
\hline ,642(a) & 0,413 & 0,403 & 0,57421 \\
\hline \multicolumn{2}{|c|}{ a Bağımsız Değişkenler: (Sabit), parasal değer, dış dizayn/boyut } \\
\hline \multicolumn{3}{|c|}{ b Bağımlı Değişken: genel memnuniyet düzeyi } \\
\hline
\end{tabular}

Tablo 19’ da yer alan R ve $\mathrm{R}^{2}$ değerleri, kurulan regresyon modelinin açıklayıcılık gücünü göstermektedir. Yapılan regresyon analizi sonucunda bağımsız değişkenlerin bağımlı değişkeni açıklama oranı \% 41,3 olarak bulunmuştur. Ayrıca katsayılar tablosu incelendiğinde bu açıklayıcılığa en büyük katkıyı dış dizayn/boyut değişkeninin sağladığg görülmektedir.

\section{Araç Kullanımı ve Sahiplik Değişkenleri-Genel Memnuniyet Düzeyi İlişkisi}

Çalışmanın bu bölümünde araç kullanımı ve sahiplikle ilgili değişkenlerin genel memnuniyet düzeyi üzerinde etkisi olup olmadığ incelenmiştir. Bu kapsamda araç kullanımı ve sahiplikle ilgili değişkenlerin bağımsız değişken, genel memnuniyet düzeyinin de bağımlı değişken olarak ele alındığı çoklu regresyon modeli test edilmiştir.

H0: Araç kullanımı ve sahiplikle ilgili değişkenler genel memnuniyet düzeyi değişkenini açıklamada istatistiksel olarak anlamsızdir. 
H1: Araç kullanımı ve sahiplikle ilgili değişkenler genel memnuniyet düzeyi değişkenini açıklamada istatistiksel olarak anlamlıdır.

Tablo 20: Araç Kullanımı ve Sahiplikle İlgili Değişkenler-Genel Memnuniyet Düzeyi İlişsisi Anova Tablosu

\begin{tabular}{|c|c|c|c|c|c|}
\hline & Kareler Toplamı & Serbestlik Derecesi (df) & Kareler Ortalaması & F & p \\
\hline Regresyon & 46,467 & 11 & 4,224 & 20,994 &, $000(\mathrm{a})$ \\
\hline Artık & 23,139 & 115 & 0,201 & & \\
\hline Toplam & 69,606 & 126 & & \\
\hline \multicolumn{5}{|c|}{ a Bağımsız Değişkenler: (Sabit), Araç kullanımı ve sahiplikle ilgili değişkenler } \\
\hline \multicolumn{5}{|c|}{ b Bağımlı Değişken: Genel Memnuniyet Düzeyi }
\end{tabular}

Tablo 20' deki ANOVA tablosu incelendiğinde $\mathrm{F}$ değeri 43,556 ve $\mathrm{p}$ değeri 0,00 olduğundan $\mathrm{H}_{0}$ hipotezinin reddine karar verilir. Buna göre oluşturulan regresyon modeli istatistiksel olarak anlamlıdır. Yani genel memnuniyet düzeyi değişkenini araç kullanımı ve sahiplikle ilgili değişkenlerden en az biri ile tahmin etmek istatistiksel olarak mümkündür.

Tablo 21: Araç Kullanımı ve Sahiplikle İlgili Değişkenler-Genel Memnuniyet Düzeyi İlişsisi Regresyon Katsayıları

\begin{tabular}{|c|c|c|c|c|c|c|c|}
\hline & \multicolumn{2}{|c|}{$\begin{array}{c}\text { Standardize } \\
\text { Edilmemiş Katsayılar }\end{array}$} & \multirow{2}{*}{$\begin{array}{c}\begin{array}{c}\text { Standardize } \\
\text { Katsayılar }\end{array} \\
\text { Beta } \\
\end{array}$} & \multirow[t]{2}{*}{$\mathbf{t}$} & \multirow{2}{*}{$\mathbf{p}$} & \multicolumn{2}{|c|}{$\begin{array}{l}\text { Çoklu Bağıntı } \\
\text { İstatistikleri }\end{array}$} \\
\hline & B & Std. Hata & & & & B & VIF \\
\hline (Sabit) & 0,388 & 0,295 & & 1,313 & 0,192 & & \\
\hline Parasal değeri & 0,273 & 0,067 & 0,27 & 4,064 & 0 & 0,653 & 1,532 \\
\hline Yakıt tüketimi & 0,051 & 0,059 & 0,06 & 0,858 & 0,393 & 0,589 & 1,697 \\
\hline Güç & 0,035 & 0,1 & 0,041 & 0,349 & 0,728 & 0,213 & 4,689 \\
\hline Sürüş konforu & 0,3 & 0,098 & 0,32 & 3,047 & 0,003 & 0,262 & 3,823 \\
\hline Performans & $-0,119$ & 0,111 & $-0,122$ & $-1,068$ & 0,288 & 0,221 & 4,53 \\
\hline Güvenlik & $-0,037$ & 0,1 & $-0,041$ & $-0,369$ & 0,712 & 0,231 & 4,329 \\
\hline $\begin{array}{c}\text { Donanım ve iç } \\
\text { dizayn }\end{array}$ & 0,04 & 0,07 & 0,05 & 0,57 & 0,57 & 0,38 & 2,633 \\
\hline $\begin{array}{c}\text { Diş dizayn / } \\
\text { boyut }\end{array}$ & 0,023 & 0,083 & 0,025 & 0,283 & 0,778 & 0,371 & 2,693 \\
\hline $\begin{array}{l}\text { Satış sonrasi } \\
\text { bakım }\end{array}$ & $-0,004$ & 0,06 & $-0,005$ & $-0,062$ & 0,951 & 0,53 & 1,888 \\
\hline Çevre dostu & $-0,017$ & 0,063 & $-0,022$ & $-0,276$ & 0,783 & 0,461 & 2,169 \\
\hline Marka & 0,403 & 0,073 & 0,467 & 5,492 & 0 & 0,4 & 2,5 \\
\hline & & a Bağın & ğişken: gene & nuniyet c & & & \\
\hline
\end{tabular}

Tablo 21 incelendiğinde parasal değer, sürüş konforu ve marka değişkenleri için p değerleri 0,05 ' ten küçük olduğu için bu değişkenler genel memnuniyet düzeyi değişkenini açıklamada istatistiksel olarak anlamlıdır. Diğer değişkenlerin modelde yer alması istatistiksel olarak anlamsız bulunmuştur. Bu değişkenler çıkarılarak model tekrar test edilir.

Yeni modelin anova tablosunda p değeri 0,05 ' ten küçük olduğu için model anlamlı bulunmuştur. 
Tablo 22: Revize Model Regresyon Katsayıları

\begin{tabular}{|c|c|c|c|c|c|c|c|}
\hline & \multicolumn{2}{|c|}{$\begin{array}{c}\text { Standardize } \\
\text { Edilmemiş Katsayılar }\end{array}$} & \multirow{2}{*}{$\begin{array}{c}\text { Standardize } \\
\text { Katsayılar } \\
\text { Beta }\end{array}$} & \multirow[t]{2}{*}{$\mathbf{t}$} & \multirow{2}{*}{$\mathbf{p}$} & \multicolumn{2}{|c|}{$\begin{array}{l}\text { Çoklu Bağıntı } \\
\text { İstatistikleri }\end{array}$} \\
\hline & B & Std. Hata & & & & B & VIF \\
\hline (Sabit) & 0,44 & 0,272 & & 1,621 & 0,108 & & \\
\hline Parasal değeri & 0,259 & 0,058 & 0,257 & 4,498 & 0 & 0,85 & 1,177 \\
\hline Sürüş konforu & 0,277 & 0,06 & 0,296 & 4,615 & 0 & 0,677 & 1,477 \\
\hline Marka & 0,402 & 0,057 & 0,466 & 7,088 & 0 & 0,644 & 1,554 \\
\hline
\end{tabular}

Tablo 22 incelendiğinde bağımsız değişkenler için $p$ değerleri 0,05' ten küçük olduğu için bu değişkenler genel memnuniyet düzeyi değişkenini açıklamada istatistiksel olarak anlamlıdır. Ayrıca tablo 22' deki VIF değerlerinin 10 değerinden küçük olduğu, dolayısıyla değişkenler arasında çoklu bağlantı olmadığına karar verilebilir. Buna göre bahsi geçen regresyon modeli şu şekilde kurulabilir:

Genel memnuniyet düzeyi $=$ 0,259 Parasal değer + 0,277 Sürüş konforu $+0,402$ Marka

Tablo 23: Revize Regresyon Model Özeti

\begin{tabular}{|c|l|l|l|}
\hline $\mathbf{R}$ & \multicolumn{1}{|c|}{$\mathbf{R}^{\mathbf{2}}$} & \multicolumn{1}{|c|}{ Düzeltilmiş $\mathbf{R}^{\mathbf{2}}$} & \multicolumn{1}{c|}{ Tahminin Std. Hatası } \\
\hline ,811(a) & 0,659 & 0,65 & 0,43961 \\
\hline \multicolumn{3}{|c|}{ a Bağımsı Değişkenler: (Sabit), parasal değer, sürüş konforu, marka } \\
\hline \multicolumn{4}{|c}{ b Bağımlı Değişken: genel memnuniyet düzeyi } \\
\hline
\end{tabular}

Tablo 23' te yer alan $\mathrm{R}$ ve $\mathrm{R}^{2}$ değerleri kurulan regresyon modelinin açıklayıcılık gücünü göstermektedir. Yapılan regresyon analizi sonucunda bağımsız değişkenlerin bağımlı değişkeni açıklama oranı \%65,9 olarak bulunmuştur. Ayrıca katsayılar tablosu incelendiğinde bu açıklayıcılığa en büyük katkıyı marka değişkeninin sağladığı görülmektedir.

\section{SONUÇ}

$\mathrm{Bu}$ çalışma ile Selçuk üniversitesi akademisyenlerinin araç satın alma davranışlarının incelenmesi amaçlanmıştır. Bu amaç doğrultusunda çalışma, Türkiye' nin ilk on girişimci üniversitesi arasında yer alan Selçuk Üniversitesi' nde uygulanmış ve tüketicilerin satın alma davranış biçimlerini anlayabilmek üzere sürekli gelişen ve kendini revize eden bir sektör olan otomotiv sektörü seçilmiştir. Bunun yanı sıra otomobil satın alma eylemi, tüketicilerin yaptıkları harcama kalemleri arasında hatırı sayılır bir yere sahiptir. Dolayısıyla bir otomobil tercihinde her türlü faktörün değerlendirilip en doğru kararın verilebilmesi de oldukça kritiktir. Diğer taraftan çalışmanın işletmelerin pazarlama faaliyetlerine ışık tutacak bilgiler içeriyor olması da bu önemi desteklemektedir.

$\mathrm{Bu}$ anlayış doğrultusunda, çalışmada katılımcılar rastgele örneklem yöntemiyle seçilmiş ve görüşmeler yüz yüze yapılmıştır. Toplamda 135 anket cevaplanmıştır. \%10 örneklem hatası ile ulaşılan anket sayısı istatistiksel olarak yeterli bulunmuştur. Katılımcıların \%64,6' sı erkek, \%35, 4' ü kadındır. Akademisyenlere araştırma ile ilgili olarak gelir, araç kullanımı, otomobil tercihi, otomobil fiyatı, otomobil markası, satın almada kullanılan bilgi kaynakları, satın alma kararı ve eylemi arasında geçen süre, satın alma kararının çevre ile paylaşılma durumu, bayi ziyareti, satın alma kararındaki etki, satın alma sürecindeki etki ve son olarak otomobil kullanan kişi olmak üzere toplam 11 soru sorulmuştur.

Elde edilen bulgulara göre, satın alınan otomobilin fiyatına göre genel memnuniyet düzeyine ilişkin fark testi ile ilgili olarak, tek yönlü anova testi yapılmadan önce grupların varyanslarının eşitliği levene testi ile test edilmiştir. Levene testinin sonucuna göre genel memnuniyet düzeyi değişkeni için grupların eşitliği söz konusudur (p: 0,057>0,05). Yani $\mathrm{H}_{0}$ : Genel memnuniyet düzeyine göre satın alınan otomobil fiyatı değişkeni 
gruplarının varyansları eşittir hipotezi anlamlı çıkmıştır. Bu sonuçlara göre tek yönlü anova testinin ön şartı sağlanmıştır. Satın alınan otomobil fiyatına göre yapılan anova testinin sonucunda, genel memnuniyet düzeyi 0,107' dir. $\mathrm{p}>0,05$ olduğu için $\mathrm{H}_{0}$ hipotezi kabul edilir. Yani satın alınan otomobil fiyatına göre genel memnuniyet düzeyi farkl1lık göstermemiştir. Satın almadaki etki düzeyine göre genel memnuniyet düzeyine ilişkin fark testine göre, genel memnuniyet düzeyi 0,468' dir. Levene testinin sonucuna göre, genel memnuniyet düzeyi değişkeni için grupların eşitliği söz konusudur (p: 0,468>0,05). Bu sonuçlara göre tek yönlü anova testinin ön şartı sağlanmıştır. Satın almadaki etki düzeyi anova testinin sonucuna göre, genel memnuniyet düzeyi 0,015 olarak gerçekleştiği ve $\mathrm{p}<0,05$ olduğu için, $\mathrm{H}_{0}$ hipotezi reddedilmiştir. Yani satın alınan otomobil fiyatına göre genel memnuniyet düzeyi farklılık göstermiştir. Scheffe ve Tukey testi sonuçlarına göre "tek karar verici benim", "karar vericilerden biriyim ve belirleyici rolüm yok", grupları, "karar vericilerden biriyim ve belirleyici rolüm var" ve "karar vericilerden biriyim ve belirleyici rolüm yok" grupları arasında anlamlı farklılıklar görülmüştür. Bu gruplar arasında tek karar verici olan kişilerin karar vermede belirleyici rolü olmayan kişilere göre, karar vermede belirleyici rolü olan kişilerin belirleyici rolü olmayan kişilere göre genel memnuniyet düzeylerinin daha yüksek olduğu görülmüştür. Parasal değer ve dış dizayn/boyut değişkenlerinin genel memnuniyet düzeyi üzerinde etkisi olup olmadığının analizi için parasal değer ve dış dizayn/boyut değişkenlerinin bağımsız değişken, genel memnuniyet düzeyinin de bağımlı değişken olarak ele alındığı çoklu regresyon modeli test edilmiştir. Yapılan anova tablosu ile F değeri 43,556 ve $\mathrm{p}$ değeri 0,00 olduğundan $\mathrm{H}_{0}$ hipotezinin reddine karar verilmiştir. Buna göre oluşturulan regresyon modeli istatistiksel olarak anlamlıdır. Yani genel memnuniyet düzeyi değişkenini parasal değer ve dış dizayn/boyut değişkenlerinden en az biri ile tahmin etmek istatistiksel olarak mümkündür.

Parasal değer, dış dizayn/boyut değişkenleri-genel memnuniyet düzeyi ilişkisi regresyon katsayılarına bakıldığında, parasal değer ve dış dizayn değişkenleri için p değerleri 0,05 ' ten küçük olduğu için bu değişkenler genel memnuniyet düzeyi değişkenini açıklamada istatistiksel olarak anlamlı çıkmıştır. Ayrıca VIF değerlerinin 10 değerinden küçük olduğu ve değişkenler arasında çoklu bağlantı olmadığına karar verilmiştir. Parasal değer, dış dizayn/boyut boyutları-genel memnuniyet düzeyi ilişkisi regresyon model özetinde, $\mathrm{R}$ ve $\mathrm{R}^{2}$ değerleri kurulan regresyon modelinin açıklayıcılık gücünü göstermiştir. Yapılan regresyon analizi sonucunda ise, bağımsız değişkenlerin bağımlı değişkeni açıklama oranı \% 41,3 olarak hesaplanmıştır. Ayrıca katsayılar tablosu incelendiğinde bu açılayıcılığa en büyük katkıyı dış dizayn/boyut değişkeninin sağladığı görülmüştür. Araç kullanımı ve sahiplikle ilgili değişkenlerin genel memnuniyet düzeyi üzerindeki etkisi incelenmiş ve bu kapsamda araç kullanımı ve sahiplikle ilgili değişkenlerin bağımsız değişken, genel memnuniyet düzeyinin de bağımlı değişken olarak ele alındığı çoklu regresyon modeli test edilmiştir. Bunun için düzenlenen anova tablosuyla, $\mathrm{F}$ değeri 43,556 ve $\mathrm{p}$ değeri 0,00 olduğundan $\mathrm{H}_{0}$ hipotezinin reddine karar verilmiştir. Buna göre oluşturulan regresyon modeli istatistiksel olarak anlamlı bulunmuştur. Yani genel memnuniyet düzeyi değişkenini araç kullanımı ve sahiplikle ilgili değişkenlerden en az biri ile tahmin etmek istatistiksel olarak mümkündür. Araç kullanımı ve sahiplikle ilgili değişkenler- genel memnuniyet düzeyi ilişkisi regresyon katsayıları incelendiğinde parasal değer, sürüş konforu ve marka değişkenleri için p değerleri 0,05 ' ten küçük olduğu için bu değişkenler genel memnuniyet düzeyi değişkenini açıklamada istatistiksel olarak anlamlı çıkmıştır. Diğer değişkenlerin modelde yer alması istatistiksel olarak anlamsız bulunmuştur. Bu değişkenler çıkarılarak model tekrar test edilmiş ve yeni modelin anova tablosunda p değeri 0,05 ' ten küçük olduğu için model anlamlı bulunmuştur. Revize model regresyon katsayılarına bakıldığında, bağımsız değişkenler için $\mathrm{p}$ değerleri 0,05 ' ten küçük olduğu için bu değiş̧kenler bağımlı değişken olan genel memnuniyet düzeyi değişkenini açıklamada istatistiksel olarak anlamlı bulunmuştur. VIF değerlerinin 10 değerinden küçük olduğu ve değişkenler arasında çoklu bağlantı olmadığına karar verilmiştir. Revize regresyon model özetinde $\mathrm{R}$ ve $\mathrm{R}^{2}$ değerleri kurulan regresyon modelinin açıklayıc1lık gücünü göstermiştir. 
Yapılan regresyon analizi sonucunda bağımsız değişkenlerin bağımlı değişkeni açıklama oranı \%65,9 olarak bulunmuştur. Ayrıca katsayılar tablosu incelendiğinde bu açıklayıcılığa en büyük katkıyı marka değişkeninin sağladığı görülmüştür.

Nihayet, \%5 anlamlılık düzeyinde genel memnuniyet düzeyi değişkenini açılamada marka, parasal değer ve sürüş konforu istatistiksel olarak anlamlı bulunmuştur. Bu açıklayıcılığa en büyük katkıyı marka değişkeninin sağladığı görülmüştür. Dış dizayn/boyut değişkeninin de genel memnuniyet düzeyine katkısının fazla olduğu tespit edilmiştir. Ve tek karar verici olan kişilerle karar vermede belirleyici rolü olan kişilerin karar vermede belirleyici rolü olmayan kişilere göre genel memnuniyet düzeylerinin daha yüksek olduğu sonucuna ulaşılmıştır. 


\section{KAYNAKÇA}

Aksoy, T. (2011). Adama ve Duruma Göre Satın Almak, Erişim Tarihi: 03.09.2015, http://www.temelaksoy.com/?s=adama+ve+duruma+g\%C3\%B6re

Altıntaş, H. (2001). Tüketici Davranışlarını Etkileyen Güncel Konular ve Tüketici Davranışlarındaki Teorik $\begin{array}{llll}\text { Değişimler. } & \text { Erişim 20.07.2015, }\end{array}$ http://www.isgucdergi.org/?p=article \&id=104\&cilt=3\&sayi $=1 \&$ yil $=2001$

Altunışık, R., Özdemir, Ş. ve Torlak, Ö. (2001). Modern Pazarlama. 1. Baskı, İstanbul: Değişim Yayınları.

AMA. (2015). Definition of customer. Erişim Tarihi: 11.07.2015, https://www.ama.org/resources/Pages/Dictionary.aspx?dLetter=C

Ankara Barosu Tüketici Hakları Kurulu. (2014). 4077 ve 6502 Sayılı Tüketicinin Korunması Hakkındaki Kanun Karşılaştırması. Ankara.

Arıtan, T. ve Akyüz, A. M. (2015). Tüketicilerin Otomobil Markalarına Yönelik Marka Sadakatleri ve Tercihleri Üzerine Bir Araştırma. Uluslararası Yönetim İktisat ve İşletme Dergisi, 11, 26, 195-220.

Arslan, K. (2003). Otomobil Alımında Tüketici Davranışlarını Etkileyen Faktörler. İstanbul Ticaret Üniversitesi Dergisi, 83-103.

Aydın, S. (2010). Hedonik Alışverişin Cinsiyet, Gelir ve Yerleşim Büyüklüğüne Göre Farklılaşması Üzerine Bir Araştırma. Süleyman Demirel Üniversitesi İktisadi ve İdari Bilimler Fakültesi Dergisi, 15, 3, 435452.

Barley, S. R. (2015). Why The Internet Makes Buying A Car Less Loathsome: How Technologies Change Role Relations. Academy of Management Discoveries, 1, 1, 31-60.

Boyraz, E. (2012, Mayıs). Eşitlik Alışverişte Bozuluyor mu? Kadınların ve Erkeklerin Alışveriş Stillerindeki Farklar Üzerine Bir Araştırma. 11. Ulusal İşletmecilik Kongresi Konya, Türkiye, 45-49.

Burton, D. (2002). Postmodernism, Social Relations and Remote Shopping. European Journal of Marketing, $36,7-8,792-810$.

Cemalcılar, İ. (1999). Pazarlama. Tıpkı Baskı, İstanbul: Beta Yayımcılık.

Cömert, Y. ve Durmaz, Y. (2006). Tüketicinin Tatmini ile Satın Alma Davranışlarını Etkileyen Faktörlere Bütünleşik Yaklaşım ve Adıyaman İlinde Bir Alan Çalışması. Journal of Yaşar University, 1(4), 356.

Craig, A. M. \& Bush, A. J. (2000). Do Role Models Influence Teenagers' Purchase Intentions and Behavior?. Journal of Consumer Marketing, 17, 5, 441 - 443.

Çağlar, İ. ve Kılıç, S. (2005). Pazarlama. 1.Baskı, Ankara: Nobel Baskıevi.

Çekmecelioğlu, H. (2006). İş Tatmini ve Örgütsel Bağlılık Tutumlarının İşten Ayrılma Niyeti ve Verimlilik Üzerindeki Etkilerinin Değerlendirilmesi: Bir Araştırma. İş, Güç Endüstri İlişkileri ve İnsan Kaynakları Dergisi, 8, 2,153-159.

Deniz, M. H. (2011). Markalı Ürün Tercihlerinin Satın Alma Davranıșları Üzerindeki Etkisi. Journal of Social Policy Conferences, 61, 2, 250-251.

Diner, U. A. (2008). Bütünleşik Pazarlama İletişimi Açısından İlişki Pazarlaması ve Kişiye Özel Reklamlar, Yüksek Lisans Tezi, Kocaeli Üniversitesi Sosyal Bilimler Enstitüsü, Kocaeli.

Doğan, H. (2002). Pazarlama Üzerine Makaleler ve Akademik Liderlik Kavramı. 1. Bask1, Isparta: Fakülte Yayınevi.

Durmaz, M. (1999). Tüketici Davranışları. 2. Baskı, İzmir: Ege Üniversitesi Baskıevi.

Durmaz, Y., Oruç, R. B. ve Kurtlar, M. (2011). Kişisel Faktörlerin Tüketici Satın Alma Davranışlarına Etkisi Üzerine Bir Araştırma. Akademik Yaklaşımlar Dergisi, 2, 1, 119.

Erce, H. (2016). Otomotiv Distribütörleri Derneği (ODD), 6, 3.

Ergin, E. A. ve Akbay, H. Ö. (2011). Giyim ve Gıda Ürünleri Kategorilerinde Tüketicilerin Plansız Satın Alma Davranışları Üzerine Bir Araştırma. Afyon Kocatepe Üniversitesi İ.İ.B.F. Dergisi, 13, 2, 275-292.

Essien, E. E. \& Udo-Imeh, P. T. (2013). A Review of Organizational Buyer Behavior Models and Theories. Journal of Research in National Development, 11(1), 55-56.

Güven, Ö. Z. ve Davudov, G. (2012). Türkiye ve Azerbaycan'da Tüketicilerin Otomobil Satın Alımına Etki Eden Faktörlerin Belirlenmesi ve Karşılaştırılmasına Yönelik Bir Araştırma. Akademik Bakış Dergisi, 30 Mayıs - Haziran, 1-20.

Hatiboğlu, Z. (1993). Temel Pazarlama. 1.Bask1, İstanbul: Beta Yayınları.

Karabacak, E. (1993). Medyanın Tüketici Davranışları Üzerindeki Etkisi ve Pazarlama Yönetimi Açısından Önemi, Yayımlanmamış Yüksek Lisans Tezi, Selçuk Üniversitesi Sosyal Bilimler Enstitüsü, Konya.

Karabulut, M. (1989). Tüketici Davranışı. 3. Baskı, İstanbul: Yön Ajans.

Karafakıoğlu, M. (2006). Pazarlama ilkeleri. Genişletilmiş 2. Baskı, İstanbul: Literatür Yayınları. 
Kim, J., Lim, J.S. \& Bhargava, M. (1998). The Role of Affect in Attitude Formation: A Classical Conditioning Approach. Journal of the Academy of Marketing Sciences, 26, 2, 143-144.

Kotler, P. (2000a). Kotler ve Pazarlama. (Çev. A. Özyağcılar). İstanbul: Sistem Yayıncılık.

Kotler, P. (2000b). Pazarlama Yönetimi. (Çev. N. Muallimoğlu). İstanbul: Beta Bask1.

Köksal, Y. ve Türedi, M. K. (2014). Tüketici Otomobil Tercihinde Etkili Olan Bilgi ve İletişim Kanalları Üzerine Bir İnceleme. Balıkesir Üniversitesi Sosyal Bilimler Enstitüsü, 17, 32, 105-125.

Li, H., Daugherty, T. \& Biocca, F. (2001). The Role of Virtual Experience in Consumer Learning, Journal of Consumer Psychology, 3-6.

Luna, D. \& Gupta, S. F. (2001). An Integrative Frame Work for Cross-Cultural Consumer Behavior. International Marketing Review, 18, 1, 45-69.

Marcus, C. Jr., Janiszewski, C. \& Laran, J. (2008). Protection of Prior Learning in Complex Consumer Learning Environments. Journal of Consumer Research, 34, 850-854.

Mathur, A., Moschis, P. G. \& Lee, E. (2003). Life Events and Brand Preference Changes. Journal of Consumer Behaviour, 3, 2, 129-132.

MEB. (2012). Tüketici Davranış Modelleri, No: 241TP0060-25 Ankara.

Moore, E. S. \& Lutz, R. J. (2000). Children, Advertising and Product Experiences: A Multimethod Inquiry. Journal of Consumer Research, 27, 31-36.

Mucuk, İ. (2004). Pazarlama İlkeleri. Yenilenmiş 14. Bask1, İstanbul: Türkmen Kitabevi.

Mukherji, A. \& Mukherji, J. (1998). Structuring Organizations For the Future: Analyzing and Managing Change. Management Decision, 36, 4, 265-273.

Nazik, M. H. (2014). Türkiye Tüketici Profili ve Bilinç Seviyesi Araştırması. İçinde A. B. Hayta, G. K. Erdamar, ve H. Demirel (ed.), Tüketici ve Çevre Edinme Vakfi, (ss. 21-25).

Niestroj, J. (2014). Typology of Consumers' Purchase Behavior on Passenger-Car Market in Poland. Journal of Economicsand Management, Vol. 15, 61-78.

Odabaşı, Y. (2012). Tüketici Davranışları. 1. Baskı, Eskişehir: Anadolu Üniversitesi Web-Ofset Tesisleri.

Odabaşı, Y. ve Barış, G. (2014). Tüketici Davranışı. 14. Baskı, İstanbul: MediaCat Yayınları.

Oluç, M. (2006). Temel Pazarlama Kavramları. 1. Baskı, İstanbul: Beta Yayıncılık.

Osselaer, S.M.J.V. \& Janiszewski, C. (2001). Two Ways of Learning Brand Associations. Journal of Consumer Research, 28, 2, 202-206.

Özcan, S. O. (2010). İnternet Pazarlama Faaliyetlerinde Tüketici Satın Alma Karar Süreci. İnternet Uygulamaları ve Yönetimi Dergisi IUYD, 1, 2, 30.

Özdemir, Ş. ve Yaman, F. (2007). Hedonik Alışverişin Cinsiyete Göre Farklılaşması Üzerine Bir Araştırma. Eskişehir Osmangazi Üniversitesi İ.İ.B.F. Dergisi, 2, 2, 211-229.

Papatya, N. (2005). Tüketici Davranışları ile İlgili Motivasyon Modelleri: Bir Perakende İşletmesinde Temizlik ve Kişisel Bakım Ürünlerine Bağlı Bir Araştırma. Süleyman Demirel Üniversitesi İktisadi ve İdari Bilimler Fakültesi Dergisi, 10, 1, 223.

Perreault, W. D., Cannon, J. P. \& McCarthy, E. J. (2013). Pazarlamanın Temelleri Bir Pazarlama Stratejisi Planlama Yaklaşımı. (Çev. A. G. Önce). 13. Baskı, Ankara: Nobel Yayıncılık.

Raj, M.P.M., Sasikumar, J. \& Sriram, S. (2013). A Study of Customers Brand Preference in Suvs and Muvs: Effect on Marketing Mix Variables. International Referred ResearchJournal, 4, 1, 48-58.

Ruhlusaraç, M. ve Nakip, M. (2016). Akademisyenlerin Otomobil Satın Alım Tercihlerini Etkileyen Faktörler. Uluslararası Bilimsel Araştırmalar Dergisi, 1, 1, 100-111.

Sağlam, T. (2013). Affluenza Tübitak Projesi. Erişim Tarihi: 20.07.2015, http://affluenzaimkb.blogspot.com.tr/

Saydan, R. (2008). Otomobil Seçiminde Etkili Olan Hedonik ve Rasyonel Yararlar Demografik Faktörlere Göre Değişiklik Gösteriyor mu? Van İli Uygulaması. Finans Politik \& Ekonomik Yorumlar, 45, 525, 97.

Shende, V. (2014). Analysis of Research in Consumer Behavior of Automobile Passenger Car Customer. International Journal of Scientific and Research Publications. 4, 2, 1-8.

Shoaf, F. R., Scattone, J., Morrin, M. \& Maheswaran, D. (1995). Gender Differences in Adolescent Compulsive Consumption. Erişim 20.07.2015, http://acrwebsite.org/volumes/7796/volumes/v22/NA-22

Tek, Ö. B. (1990). Pazarlama İlkeler ve Uygulamalar, İzmir: Memleket Gazetecilik ve Matbaacilık,.

Tekin, M., Güleş, H. K. ve Öğüt, A. (2010). Değişim Çağında Teknoloji Yönetimi, 5. Baskı, Ankara: Gazi Kitabevi.

Tenekecioğlu, B. (2009). Pazarlama Yönetimi. Eskişehir: Anadolu Üniversitesi Web-Ofset Tesisleri. 
TSE. (2015). Standart Ekonomik ve Teknik Dergisi. Erişim Tarihi: 11.07.2015, http://www.tse.org.tr/upload/tr/dosya/icerikyonetimi/4771/28042015152005-2.pdf

Uzunoğlu, E. (2005). Müşteri Odaklı Pazarlama Anlayışı Açısından Değer Zinciri Yönetimi ve Değer Zincirinde İletişimin Yeri ve Önemi, Yayımlanmamış Doktora Tezi, Ege Üniversitesi Sosyal Bilimler Enstitüsü, İzmir.

Yayar, R., Çoban, M.N. ve Tekin, B. (2015). Otomobil Sahipliğini Etkileyen Faktörlerin Belirlenmesi: Tokat İli Kentsel Alanda Bir Uygulama. Yönetim ve Ekonomi, 22, 2, 603-617.

Wood, V.R. \& Howell, R. (1991). A note on hispanic values and subculturel research,. Journal of The Academy of Marketing Science, 19, 1, 61-67. 